\title{
Facilitators and Barriers Surrounding the Role of Administration in Employee Job Satisfaction in Long-Term Care Facilities: A Systematic Review
}

\author{
Kimberly Lee *, Michael Mileski ${ }^{\circ}$, Joanna Fohn, Leah Frye and Lisa Brooks \\ School of Health Administration, Texas State University, 601 University Drive, San Marcos, TX 78666, USA; \\ mileski@txstate.edu (M.M.); jtf64@txstate.edu (J.F.); lmf106@txstate.edu (L.F.); 1lb127@txstate.edu (L.B.) \\ * Correspondence: kim.lee@txstate.edu
}

Received: 30 July 2020; Accepted: 21 September 2020; Published: 24 September 2020

\begin{abstract}
Previous literature has shown how associate engagement has positively impacted on productivity, job satisfaction, safety, retention, consumer sentiment, and financial performance in hospitals and healthcare systems. However, a lack of research showing the relationship between associate engagement and job satisfaction within the long-term care environment has existed. Our objective was to investigate characteristics within the long-term care environment that promote and detract from associate job satisfaction and extrapolate the best practices in maintaining job satisfaction and engagement. This systematic review queried CINAHL, PubMed (MEDLINE), and Academic Search Ultimate databases for peer-reviewed publications for facilitators and barriers commensurate with employee job satisfaction in long-term care facilities using the Preferred Reporting Items for Systematic Reviews and Meta-Analysis (PRISMA) and the Kruse Protocols. The authors identified 11 facilitators for job satisfaction and 18 barriers to job satisfaction in the 60 selected articles. The top four facilitators were Supportive Leadership, Capable and Motivated Employees, Positive Organizational Values, and Social Support Mechanisms. The top four barriers were condescending management style, high job demands, lack of self-care, and lack of training with medically complex patients. The systematic review revealed the importance of maintaining satisfied employees in the long-term care workplace through am emphasis leadership and on the facilitators identified to best serve their associates and improve care for residents.
\end{abstract}

Keywords: job satisfaction; associate engagement; long-term care; older adults; nursing homes; assisted living

\section{Introduction and Background}

\subsection{Introduction}

\subsubsection{Rapid Growth of $65+$ Population}

The fastest growing segment of the national and world population is the 65 years and over age bracket. World Population Ageing 2019 [1] emphasizes that the current world population of individuals at 65 years or greater numbers 703 million, with a projection of 1.5 billion in 2050. In the United States, the population of age 65 and over is at 52 million, with a projection of a doubled population of 95 million by 2060 [2,3]. In addition, a greater percentage of our total population in the US and in the world is comprised of people aged 65 and older [1-3], with a projected increase of 1 in 5 persons in the US and 1 in 6 persons in the world by 2050 [1,4]. In the United States, the number of those aged 65 and over will rise from the current $16 \%$ of total population to $23 \%$ of the total population by $2060[2,3]$. 
Technological and medical advances have further contributed to the expanding population of the 65-and-over age bracket, having led to the expectation that a senior citizen in developed country will live more than a quarter of their adult life after the age of 65. These trends apply to the United States and are included in all the world's developed countries [1].

\subsubsection{Residential and Care Needs}

With the growth in the 65-and-over population, one quickly observes the impact on the organizations providing residential and healthcare services. The National Center of Health Statistics has estimated that approximately 65,000 regulated long-term care service providers (including nursing homes, assisted living or similar residential communities, home health agencies, adult day care services, and hospice organizations) have cared for over 8.3 milling individuals in the United States [5]. Of the 65,000 service providers, 15,600 nursing homes and 28,900 assisted living or similar residential care facilities delivered care to 2.16 million residents. The estimated 1.5 million number of individuals aged 65 and over living in nursing or skilled nursing facilities is projected to rise to 2.3 million by 2030 and 3 million by 2060 [2,5]. The over-65 population residing in nursing homes and residential care communities come with a number of chronic diseases, with Alzheimer's' Disease, dementias, depression, and hypertension being most prevalent [5]. To care for an aging population with chronic medical needs, approximately 1.5 million, full-time nursing associates provide services to the residents of nursing homes and residential communities, requiring $3.80 \mathrm{~h}$ per resident in nursing homes and $2.64 \mathrm{~h}$ per resident in residential care communities [5].

\subsubsection{Burden on Society and Economics}

A growing number of elders requiring care will result in a burden on both society in general and on the support systems that sustain their health and care. Seniors will outnumber children by 2035 [2]. The Population Reference Bureau (PRB) projects that by 2030, less than 3 working age adults in the US will support every US individual over 65, a decrease from over 4 US working adults to individuals of 65 and over in 2014 [2].

With the growth of the population of the 65-and-older bracket in the coming years, determining the best systems and practices to sustain a healthy, well, and productive aging population, while also providing quality care within residential care communities and nursing homes, has become paramount for this quickly expanding population. The United Nations (2019) emphasized the importance of prolonging the wellness of the gaining population by establishing the Sustainable Development Goals (SDGs) as outlined for sustainability of care, independence, and healthy aging of the growing demographic of the 65-and-over population by the United Nations Committee on Health [1]. Many current sources recognize the importance of established policies, technology, living environments, social support mechanisms, planning, and education to help the 65-and-over population to maintain independence and self-sufficiency for longer and to relieve the economic and social burden on the younger cohorts of society [1-3].

\subsection{Background}

\subsubsection{Job Satisfaction, Associate Engagement, and Organizational Outcomes}

Previous research literature from various industries, including healthcare, has established the relationship between job satisfaction and associate engagement [6-11]. Most importantly, previous research literature focusing on the healthcare industry has also consistently established the relationship between associate engagement with organizational performance including customer and patient satisfaction in healthcare [7-10,12-14]. Most recently, in a special report on healthcare workforce engagement, Press Ganey [10] reported how associate engagement positively impacts on productivity, job satisfaction, safety, retention, consumer sentiment, and financial performance. The bulk of 
healthcare literature has been conducted with hospitals and health care systems being the primary source of the data [7-10,12-15].

Key facilitators of job satisfaction and engagement in hospitals and healthcare systems have included manager support and style [7,8,12-14], supportive workplace processes and technology [7,13,15], presence of a positive organizational culture based upon the mission and values of an organization [7-10,14], employee's feelings of making a difference, including use of and development of skills [7,11-14], meaningful and positive workplace relationships and teaming [8-11,13,14], transformational leadership style $[7,10,14]$, and frequent and transparent communication by leaders [7-10,14]. Supportive leadership included managers or leaders who both earned and extended trust between team members, demonstrated respect and caring [7,13,14], and promoted career development [11,14]. One source [12] cited supportive leadership as accounting for $63 \%$ influence over job satisfaction, compared to other factors. A positive organizational culture was defined to be mission- and values-based [7,8], promoting resilience and adaptation to change [10], inclusive of employee empowerment and shared governance [14], and based on safety, excellence, and quality of patient care [9-15].

Key barriers to job satisfaction and engagement in hospitals and health systems have included workload demands [14], limited resources and policies [11,14], limited salary and benefits [11], and more recent literature has included barriers such as presence of siloes, lack of consensus on goals, a lack of awareness on how systems integrate across functions and departments, a lack of frequent communication, and a lack of involvement around safety, quality, and the patient experience $[9,10]$.

\subsubsection{Gap of Research in the Long-Term Care Environment}

A lack of research and literature studying job satisfaction and associate engagement exists in the long-term care environment. Only recently have investigators or publications addressed long-term care specifically and acknowledged that the study of job satisfaction and/or associate engagement are critical in this setting. For example, the Centers of Medicare and Medicaid Services only recently allocated funds from the Civil Money Penalty Reinvestment Program to create a generic employee satisfaction survey, accompanying toolkits, and education materials on data collection and process-improvement strategies [16]. Thus, a gap exists in the research relative to the relationship between job satisfaction, associate engagement, the perception of quality care by residents in long-term care, and family satisfaction.

\subsubsection{Cost of Associate Disengagement}

To further draw attention to the critical impact of job satisfaction and associate engagement, it is important to consider the impact of the disengaged and dissatisfied healthcare worker on Americans' pocketbooks. One source reported that $68 \%$ of employees from all industries are not engaged and that this disengagement costs US employers $\$ 400$ billion annually [15].

\subsubsection{Societal and Public Health Crises-Multiplier of Importance of Healthcare Associate Satisfaction}

Crises such as public health pandemics (e.g., Covid-19) and natural disasters further exacerbate the sense of urgency in addressing morale and the satisfaction of healthcare team members in healthcare organizations. Recently, initial research findings and literature have emerged acknowledging the stress imposed by Covid-19 conditions on the healthcare workforce, impacting job satisfaction, morale, and risking the imposition of unintended negative impacts on patients and quality $[17,18]$. With the nursing home and other residential communities as epicenters of the Covid-19 pandemic, stress experienced by long-term care workers will certainly impact on patient satisfaction and quality of care.

\subsection{Significance and Purpose}

Given the quickly expanding over-65 population worldwide, an anticipated increased demand for nursing homes and residential care communities to care for the aging population, an increased burden 
on social and economic systems, an anticipated increase in need for nursing and care professionals, the relationship between nursing and healthcare professional's job satisfaction and engagement with patient and organizational outcomes, and the impact of public health crises and pandemics (e.g., Covid-19), a sense of urgency exists to identify systems and practices that either facilitate or impede administrators in long-term care facilities to enhance job satisfaction and improve outcomes in quality of care and organizational effectiveness [1-18]. Further to this point, the investigators' two key purposes in this study were to investigate characteristics within the long-term care environment that promote and detract from associate job satisfaction and extrapolate the best practices in maintaining job satisfaction and engagement, ultimately leading to best practices in creating a positive organizational culture for associates and a sound foundation for delivering resident-centered care within long-term care settings. The investigators used a systematic literature review method.

For the purposes of this study, the terms "associates", "employees", and "healthcare workers" were used synonymously. The investigators intentionally have utilized the word "associates" to be more inclusive, contemporary, and substantive in impacting culture. In addition, much has been written relating to job satisfaction with associate engagement. It is generally accepted that job satisfaction is a component and a contributing factor of overall associate engagement in the workplace. A number of published articles have substantiated this relationship [6,10,12-14].

\section{Materials and Methods}

This study was conducted utilizing the Preferred Reporting Items for Systematic Reviews and Meta-Analyses (PRISMA) guidelines and the Kruse Protocol for writing systematic reviews [19,20]. The initial search was conducted using Pubmed (MEDLINE), Cumulative Index of Nursing and Allied Health Literature (CINAHL), and Academic Search Ultimate. These databases were chosen due to their widespread use and availability. A Boolean search was conducted using a complex three-string search as included in Figure 1.

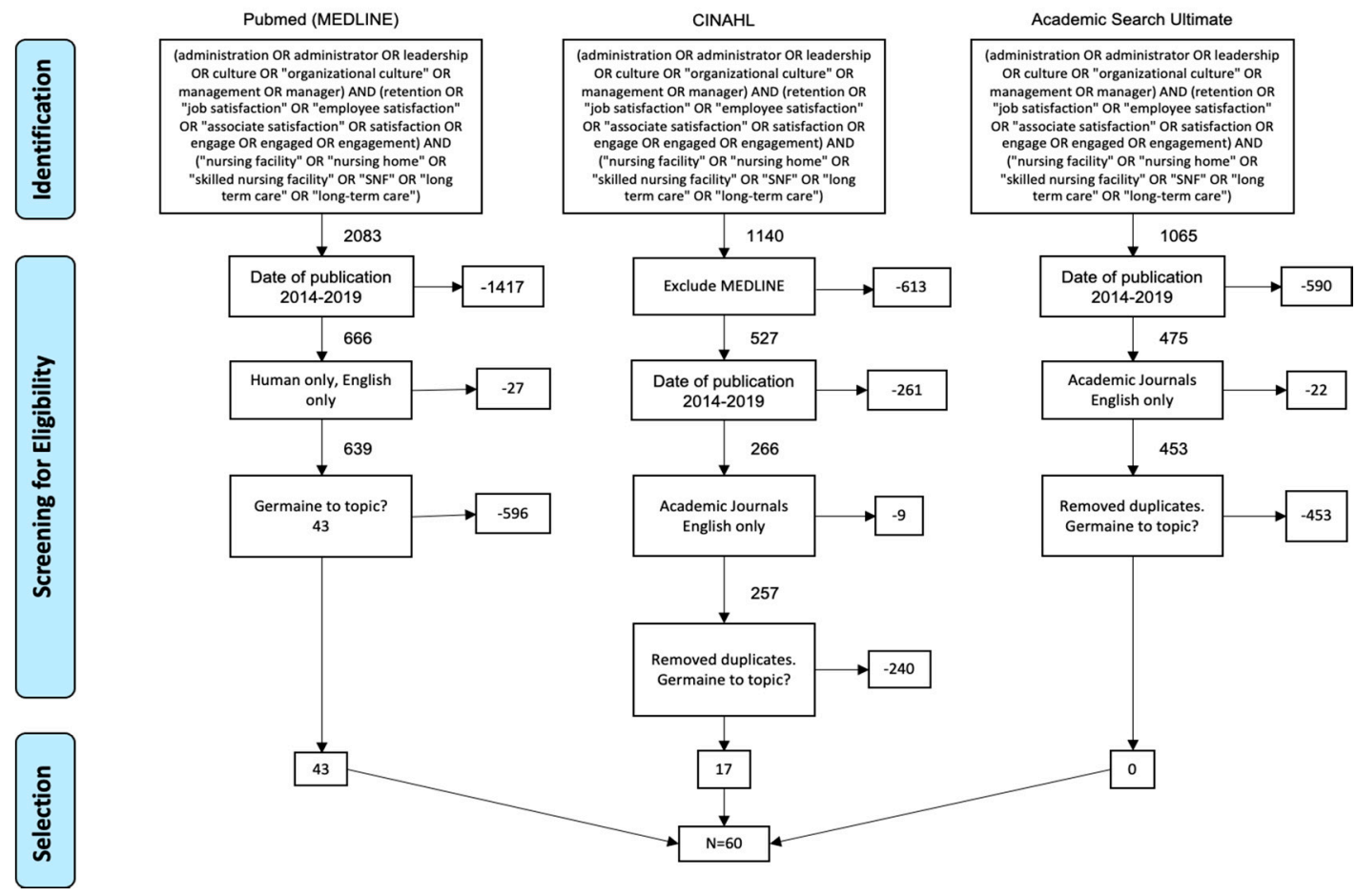

Figure 1. Preferred Reporting Items for Systematic Reviews and Meta-Analysis (PRISMA) Flow Chart.

The summary of the selected articles included the Population, Intervention, Comparison, and Outcome (PICO) requirements for Prisma guidelines [19]. The reviewers read and analyzed 
the complete articles and noted the facilitators and barriers indicated to influence job satisfaction in long-term care facilities. Each article was completely assessed by at least two reviewers and the reviewers met routinely to arrive at a consensus on the facilitators, barriers, and themes of each article. Weekly consensus meetings occurred throughout the systematic review analysis. The reviewers/authors sought to reduce the risk of bias in the analysis technique through having multiple reviews and weekly consensus meetings.

\subsection{Inclusion Criteria}

Authors reviewed articles yielded from the search, determined germane literature, and summarized themes based on consensus. Inclusion criteria included English language and peer-reviewed articles. Articles must have been published in academic journals to be included. The dates of inclusion were 1 January 2014 through to 30 September 2019. To be included, articles must have explored the effects of administration/organizational culture on job satisfaction, employee satisfaction, or employee engagement in long-term care facilities.

\subsection{Exclusion Criteria}

Articles were only included in the study if they were determined to be germane by all authors. Trade industry reports were excluded. Poster presentations were excluded. Any works without a clear peer review process were excluded. Articles which were not specific to long-term care environments were excluded. Bias was not considered when reviewing research for this study. The final sample of articles after meeting exclusion criteria was analyzed and yielded a kappa statistic $(k=1)$, which showed perfect interrater agreement [21].

\subsection{Study Selection}

The initial search resulted in 4288 results. All duplicates were removed, leaving 3675 articles. Publication time frame was limited to between 2014 and 2019, leaving 1407 articles. Additionally, only academic journals and articles in the English language were included, leaving 1349 articles. Duplicates and non-germane articles were then removed from the results, leaving 60 articles for use in this qualitative analysis and review. Authors retained articles that only occurred within long-term care facilities and included facilitators or barriers to job satisfaction of associates or employees. A summary of the articles chosen for inclusion is included in Appendix A Table A1.

\subsection{Data Analysis}

Narrative summaries related to factors that influenced job/employee satisfaction, retention, and engagement regarding administration or organizational culture in long-term care environments were extracted from each article. Summaries were then grouped into larger recurring themes that identified either key determinants or impediments to job/employee satisfaction, retention, and engagement. The themes were chosen by consensus of the authors and were chosen as they provided overarching summaries to the facilitators and barriers extracted from the articles. Themes were then summarized via two affinity matrix tables, one for facilitators and one for barriers. Tables 1 and 2 document the themes, their citation occurrence, their frequency sum, and frequency percentages. 
Table 1. Summary and frequency of facilitators identified as impacting on job satisfaction.

\begin{tabular}{|c|c|c|c|}
\hline Facilitators & $\begin{array}{l}\text { Occurrences by Article } \\
\text { Reference Number }\end{array}$ & $\begin{array}{l}\text { Total Occurrences } \\
\qquad(n=162)\end{array}$ & $\begin{array}{c}\text { Percent of } \\
\text { Occurrences }\end{array}$ \\
\hline Supportive Leadership & [22-48] & 51 & $31.48 \%$ \\
\hline Capable and Motivated Employees & {$[22,26,30,32,35,45,49-60]$} & 25 & $15.43 \%$ \\
\hline Positive Organizational Values & {$[22-24,29,31-33,48,51,53,54,57,60-64]$} & 20 & $12.35 \%$ \\
\hline Social Support Mechanisms & {$[22,23,25,29,30,34,41,45,47,65-68]$} & 15 & $9.26 \%$ \\
\hline Adequate Job Resources & {$[32,38,45,47,54,55,69-71]$} & 11 & $6.79 \%$ \\
\hline Career/Professional Development & {$[25,35,37,38,43,48,57,72,73]$} & 10 & $6.17 \%$ \\
\hline Initial Orientation and Training & {$[22,38,58,64,68,74]$} & 9 & $5.56 \%$ \\
\hline Patient-Centered Philosophy & {$[22,28,48,73,75]$} & 9 & $5.56 \%$ \\
\hline Enjoyment of Relationships with Patients & {$[25,39,40,48,72,76]$} & 7 & $4.32 \%$ \\
\hline Non-Profit Ownership & {$[53,55,63]$} & 4 & $2.47 \%$ \\
\hline Organizational Systems and Processes & [22] & 1 & $0.62 \%$ \\
\hline
\end{tabular}

Table 2. Summary and frequency of barriers identified as impacting job satisfaction.

\begin{tabular}{|c|c|c|c|}
\hline Barriers & $\begin{array}{l}\text { Occurrences by Article } \\
\text { Reference Number }\end{array}$ & $\begin{array}{c}\text { Total Occurrences } \\
(n=98)\end{array}$ & $\begin{array}{c}\text { Percent of } \\
\text { Occurrences }\end{array}$ \\
\hline Condescending Management Style & {$[27,34,35,38,41,42,46,51,66,71,77]$} & 15 & $15.31 \%$ \\
\hline High Job Demands & {$[25,38,40,43,46,65,67,71,72,77,78]$} & 13 & $13.27 \%$ \\
\hline Lack of Training with Medically Complex Patients & {$[22,24,25,65,75,79]$} & 8 & $8.16 \%$ \\
\hline Prohibitive Environmental Characteristics & {$[22,32,54,68,78]$} & 8 & $8.16 \%$ \\
\hline Lack of Leadership Training & {$[22,24,27-29,31]$} & 7 & $7.14 \%$ \\
\hline Business Aspects Interfering with Care & {$[24,80,81]$} & 7 & $7.14 \%$ \\
\hline Stress & {$[27,30,43,67]$} & 5 & $5.10 \%$ \\
\hline Lack of Access to Management & {$[22,35,41,47]$} & 4 & $4.08 \%$ \\
\hline Poor Compensation and Benefits & {$[38,39,78]$} & 3 & $3.06 \%$ \\
\hline Lack of Peer Support & {$[22,48]$} & 2 & $2.04 \%$ \\
\hline Patient Morbidity & {$[50,59]$} & 2 & $2.04 \%$ \\
\hline Limited Communication Opportunities & {$[22]$} & 1 & $1.02 \%$ \\
\hline
\end{tabular}

\section{Results}

The 60 articles included in the qualitative analysis are summarized in Appendix A Table A1, with the most recent publications listed first by their primary authors. The 60 articles yielded 162 instances of facilitators and 97 instances of barriers relative to job satisfaction in long-term care facilities.

After a number of routine, weekly consensus meetings, the reviewers counted the number of times that a facilitator theme occurred in each article and consolidated the frequency and article references in an affinity matrix for further analysis in Table 1. Twelve facilitator themes emerged from the qualitative review of full articles, with a total of 162 occurrences. The top three facilitator themes accounted for $59.26 \%$ of the total occurrences. A theme of supportive leadership occurred 51 times (31.48\%) [22-48]. Capable and motivated employees occurred 25 times (15.43\%) [22,27,30,32,35,45,49-60]. Positive organizational values occurred 20 times (12.35\%) [22-24,29,31-33,48,51,53,54,57,61-64] and social support mechanisms occurred 15 times (9.62\%) [22,23,25,29,34,41,45,47,65-68]. Adequate job resources occurred 11 times (6.79\%) [32,38,45,47,54,55,69-71] and career/professional development occurred 10 times $(6.17 \%)[25,35,37,38,43,48,57,72,73]$. Initial orientation and training $[22,38,58,64,68,74]$ and patient-centered philosophy [22,28,48,73,75] both occurred 9 times (5.56\%) respectively. Enjoyment of relationships with patients occurred 7 times $(4.32 \%)[25,39,41,48,72,76]$, non-profit ownership occurred 4 times (2.47\%) [53,55,63], and organizational systems and processes occurred once (0.62\%) [22].

The authors/reviewers identified themes of barriers through qualitative analysis and consensus meetings. The authors/reviewers counted the number of times that a barrier theme occurred in each article and consolidated the frequency of occurrence in the 60 articles in an affinity matrix, illustrated in Table 2. Eighteen barrier themes were identified in the qualitative review and barriers occurred 98 times in the review of the 60 articles. Six of the eighteen barriers accounted for $61.22 \%$ of the total barriers. Condescending management style occurred 15 times $(15.31 \%)$ [27,34,35,38,41,42,46,51,66,71,77]. High job demands, which included factors such as physical and psychological burdens [25], 
understaffing [38,46,67], heavy workloads [38,78], lack of time to complete tasks [40,43], limited staffing resources [46], reduced teamwork [46], unfair hours [67,71], regulations on nurse roll flexibility [72], and physical exhaustion [65], occurred 13 times (13.27\%) [25,38,40,43,46,65,67,71,72,77,78]. Lack of self-care as exhibited by the associates occurred 9 times $(9.18 \%) 30,33,33,46,47,54,59]$. Lack of training with medically complex patients $(8.16 \%)[22,24,25,65,75,79]$ and prohibitive environmental characteristics $[22,33,54,68]$ each occurred 8 times $(8.16 \%)$. Lack of leadership training [22,24,28,29,31] and business aspects interfering with care [80] occurred 7 times respectively (7.14\%). High coworker conflicts occurred 6 times $(6.12 \%)[34,35,46,47,78]$. Negative perceptions about coaching [31,35,39,72] and Stress [27,30,67] both occurred 5 times $(5.10 \%)$. Lack of access to management [22,35,41,47] occurred 4 times $(4.08 \%)$. Poor compensation and benefits [38,39] occurred 3 times $(3.06 \%)$. Lack of peer support $[22,48]$ and patient morbidity [50,59] occurred 2 times $(2.04 \%)$. Limited communication opportunities with leadership and team members [22], language barriers [58], non-profit ownership [77], and patient complexity [32] all appeared once (1.02\%). For clarification purposes, limited communication opportunities with leadership and team members were identified to decrease job satisfaction [22]. These results provided evidence to meet the two objectives of this study: (1) to provide a summary of facilitators and barriers of associate satisfaction in long-term care facilities, and (2) to provide a summary of the best practices that will benefit long-term care leaders and organizations in the industry. Best practices will be further discussed in the next section.

\section{Discussion}

This study provided a more comprehensive and extensive review in comparison to studies over the previous 5 years than previous studies in long-term care. Because of the extensive nature of this particular review, leaders had the opportunity to prioritize best practices and systems to enhance their own organizations and facilities. Focusing on the top categories of both facilitators and barriers will help long-term care facilities and organizations provide environments that promote both associate and resident satisfaction, while reducing costs associated with unhappy associates and residents.

\subsection{Most Impactful Themes}

Through the systematic review of the 60 selected articles, 162 occurrences of facilitators and 98 occurrences of barriers emerged. The 162 occurrences were grouped into 11 different themes for the facilitators. The eleven "facilitator" themes as demonstrated in Table 2 and represented in Figure 1 included supportive leadership [22-48], capable and motivated employees [22,27,30,32,35,45,49-60], positive organizational values [22-24,29,31-33,48,51,53,54,57,61-64], social support mechanisms, adequate job resources [32,38,45,47,54,55,69-71], career/professional development [25,35,37,38,43,48,57,72,73], initial orientation and training $[22,38,58,64,68,74]$, patient centered philosophy $[22,28,48,73,75]$, enjoyment of relationships with patients $[25,39,40,48,72,76]$, non-profit ownership [53,55,63], and organizational systems and processes [22].

As evident in Figure 2, 68.52\% of the occurrences grouped into the top four themes of supportive leadership, capable and motivated employees, positive organizational values, and social support mechanisms. One example of supportive leadership stated that employees with high job satisfaction "perceive that their leaders both support them and recognize their job contributions" [47]. One example of capable and motivated employees stated that greater job satisfaction was significantly associated with increased professional efficacy [54]. An example of positive organizational values was found in Gray [48], which states that strong teams, defined as groups that do a good job, cooperate, have mutual respect for one another, and are positively regarded by others, were a source of associate job satisfaction. Social support was found to have a positive influence on employees, improve their sense of autonomy and meaning, and reduce their stressors leading to burnout [34]. Additional examples of themes in the analyzed articles can be found in Appendix A. Enhancing supportive leadership, hiring capable team members, reinforcing capable and empowered associates, grounding a culture in values, and providing 
support can serve as the key drivers of job satisfaction towards enhanced organizational performance for leaders in the long-term care industry.

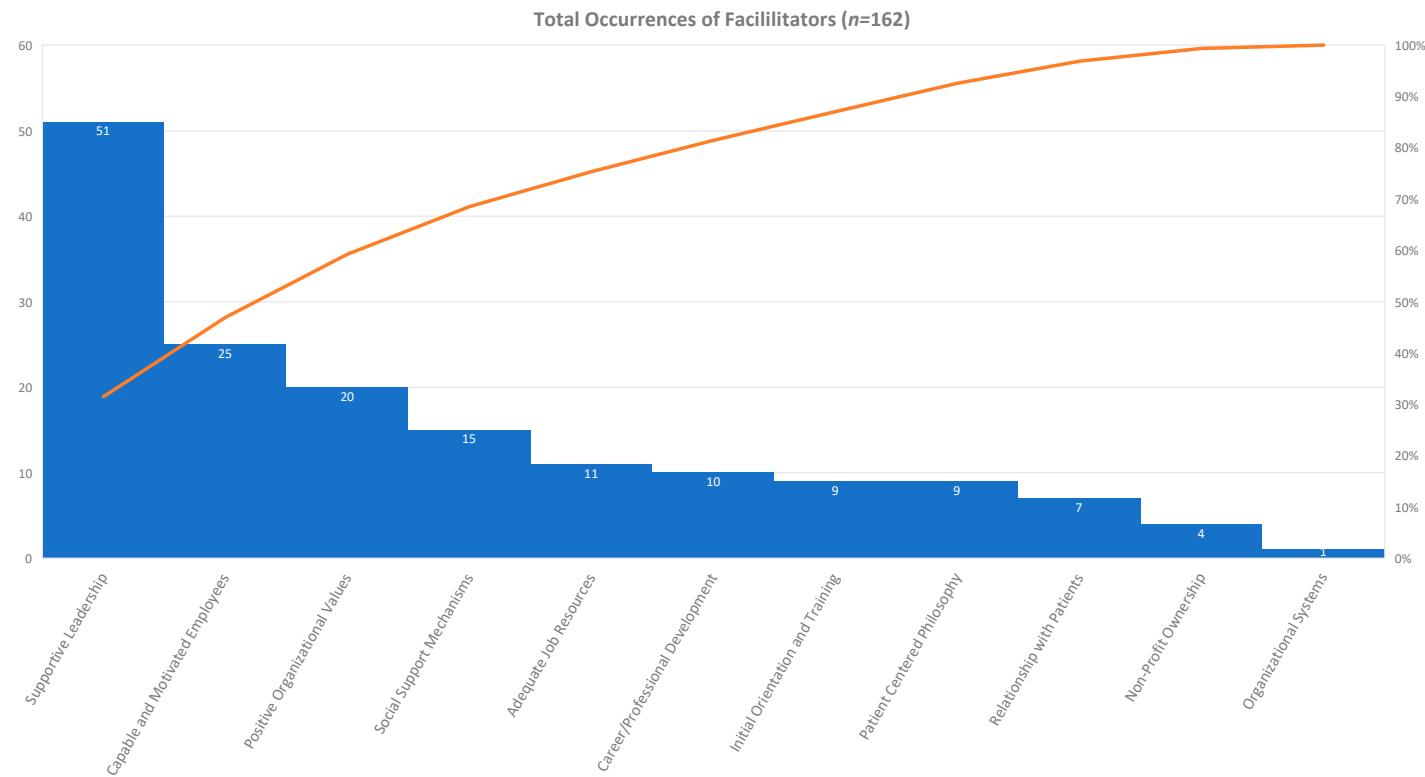

Figure 2. Total occurrences of facilitators in the review with the first four facilitators comprising $68.52 \%$ of the occurrences.

The 98 occurrences of barriers noted in this study fell into 18 categories, including condescending management style $[27,34,35,38,41,42,48,51,66,71,77]$, high job demands $[25,38,40,43,46,65,67,71,72,77,78]$, lack of self-care by employees $[30,32,33,46,47,54,59]$, lack of training with medically complex patients $[22,24,25,65,75,79]$, lack of leadership training [22,24,27-29,31], prohibitive environmental characteristics $[22,32,54,68,78]$, high coworker conflicts $[34,35,46,47,76]$, perception of business aspects interfering with care $[24,80,81]$, negative perceptions about leadership style $[31,35,39,72]$, lack of access to management [22,35,41,47], stress [27,30,42,67], lack of peer support [22,48], patient morbidity [50,59], poor compensation and benefits $[38,39,78]$, limited communication opportunities with leadership and team members [22], language barriers [59], non-profit ownership [77], and patient complexity [32]. The top themes are displayed in Table 2 and Figure 3.

The top four "barrier" themes (condescending management style, high job demands, lack of self-care, and lack of training with the medically complex patients) represented $45.92 \%$ of the total occurrences for barriers. An example of condescending management style included the withholding of information by supervisors or coworkers that leads to negative work performance [46]. An example of high job demands included heavy workload, which leads to higher stress levels and lower levels of job satisfaction [49]. Lack of self-care can affect job satisfaction through issues such as brief lunch breaks, low access to healthy foods at work and "working to the point of exhaustion" that can cause employees to be tired and too exhausted to exercise or cook a heathy meal after work [30]. Lack of training with medically complex patients can include young nurses with "less knowledge and experience with elderly care", which can lead to unrealistic expectations, leading to burnout and decreased engagement [25]. Additional examples of themes in the analyzed articles can be found in Appendix A. If the themes of lack of leadership training and prohibitive environmental characteristics were added to the top four themes, the top six "barrier" themes accounted for $61.22 \%$ of the occurrences. Administrators have the opportunity to further demonstrate their commitment to supportive leadership, empowerment of team members, positive organizational values, and social support mechanisms through managing the barriers in long-term care facilities. 


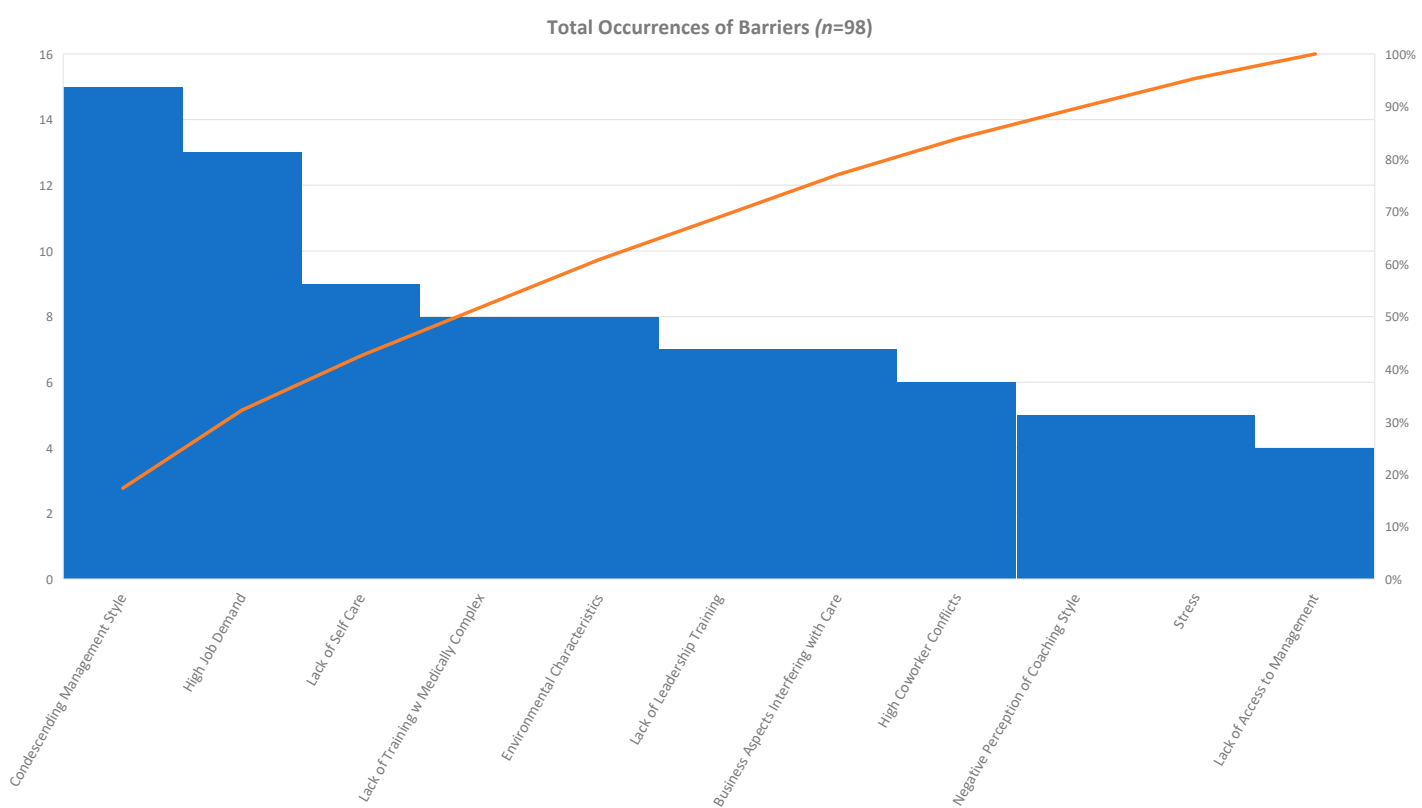

Figure 3. Total occurrences of top barriers in the review with the first six barriers comprising $60.82 \%$ of the occurrences.

\subsection{Most Impactful Categories of Themes}

The researchers noted how the themes grouped into three broad categories pertaining either to the organizational leadership, systems, or processes; to the attributes of team members, associates, or employees; and lastly to the environmental characteristics of long-term care or the nature of the work; depicted in Figure 4a,b.

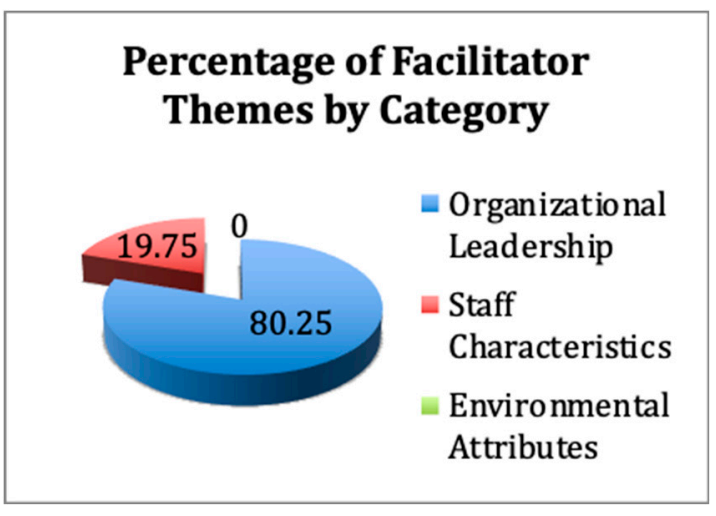

(a)

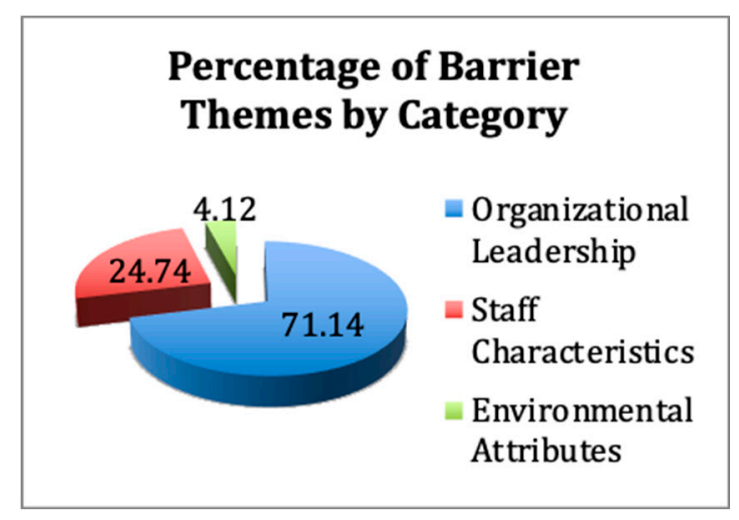

(b)

Figure 4. $(\mathbf{a}, \mathbf{b})$ Percentage of facilitators and barriers by theme category.

\subsubsection{Organizational Leadership}

Nine of the 12 "facilitator" themes $(80.25 \%$ of the occurrences in the literature) and 10 of the 18 "barrier" themes $(71.14 \%$ of the occurrences in the literature) represented organizational leadership, systems, or processes. Administrators and organizational leaders have the most control over these organizational themes' attributes. Within the category of which administrators have the most influence, supportive leadership accounted for $31.48 \%$ of the occurrences of facilitators. The findings of this study relative to the long-term care environment [22-79] reinforced the importance of leaders providing positive and empowering guidance, setting up systems to support team members, providing robust orientation and training on the specific needs of the medically complex population, 
and reinforcing the positive aspects both in the staff and in the environment, consistent with literature and findings in hospital and healthcare systems [7-15]. Supportive leadership was the most cited, influential, and positive facilitator [22-48] in long-term care settings, along with setting up systems, processes, and tools to better support associates [22,23,25,29,30,34,41,45,47,65-68], setting a positive culture [22-24,29,31-33,48,51,53,54,57,60-64], and inspiring employees [22,26,30,32,35,45,49-60].

The most impactful barrier of high job demands $[25,38,40,43,46,65,67,71,72,77,78]$, including staffing [38,46,67], workload [38,78], lack of resources [40,43,46], and the impact of regulatory requirements [72], can be alleviated by a leadership style that integrates listening, frequent communication, trust, and transparency, identified in related hospital and healthcare system literature [7-15]. In addition, a process improvement technique, such as the Kaizan approach [82], has value in engaging employees and increasing autonomy on job structure and solutions.

\subsubsection{Staff Characteristics}

The second-most influential category of themes relates to staff/employee/team member/associate/workforce attributes. Two "facilitator" themes $(19.75 \%$ of the occurrences in the literature) and five (27.54\% of the occurrences in the literature) "barrier" themes relate to staff characteristics. Capability and motivation of employees and team members enjoying their professional relationships with residents or patients represent the inherent attributes that influence associates' satisfaction $[22,25,26,30,32,35,39,40,45,48-60,72,76]$. Consistent with previous work [7-15] in healthcare, a long-term care administrator's best way of supporting associates' capabilities and enhancing motivation is through adopting a supportive and positive leadership style [7-15], the most predominant organizational characteristic influencing satisfaction as per the results in this study. A lack of self-care $[30,32,33,46,47,54,59]$, negative perceptions about a coaching style used by leadership $[31,35,39,72]$, and stress $[27,30,43,67]$ represented intrinsic staff characteristics that have the potential to respond to an administrator who provides support systems such as wellness programs, inviting breakrooms with nutritious snacks, and an open communication style, inviting feedback [7-15]. Open, transparent, and frequent communication promoted as the best practice in hospital and healthcare system literature [7-15] would serve effectively in alleviating barriers in long-term care as identified in this study [22-81].

\subsubsection{Environmental Attributes}

The least influential of the broad categories of themes was environmental attributes, aspects of providing care in long-term care facilities with the clinical complexity of the population. None of the "facilitator" themes were classified as environmental attributes and 4 of the 18 (24.49\%) "barrier" themes were classified as environmental. Patient morbidity [50,59], limited communication opportunities with leadership and team members [22], and patient complexity [32] were included in a few of the articles reviewed as posing barriers to associate satisfaction. Considering how an administrator best manages environmental attributes relative to overcoming these barriers, one could posit again that creating a positive supportive leadership style, establishing positive organizational values, and providing social support mechanisms will most influence how associates react to the environment. Interventions such as including training in techniques to cope with patient morbidity in order to better communicate and gain competence with managing patient complexity, represent examples of how an administrator can best provide support mechanisms for employees [7-15].

\subsection{Implications for Future Success in Long-Term Care and in Times of Crisis and Rapid Change}

The secondary purpose of the current study was to determine a best-practice checklist for establishing a long-term care setting, which promotes associate engagement and in turn creates a care environment focused on quality care. The study's findings suggest the best practices that could facilitate such an environment. Through the findings of this study, leaders in long-term settings are guided to engage in establishing supportive leadership. Supportive leadership, the most frequently 
cited facilitator in the study, results from the career and professional leadership development of administrators, leaders, and staff, the provision of adequate job resources, orientation, and ongoing training, specifically in terms of the medically complex. All the components that contribute to establishing a supportive leadership style were identified as facilitators.

In addition, the second-most cited facilitator of associate engagement is the presence of a capable and motivated healthcare workforce in long-term care. The secret of empowering and motivating associates comes through such facilitators as establishing social support mechanisms (the third most frequent facilitator theme), rewarding patient-centered care and philosophy, and celebrating associates' enjoyment of their professional relationships with residents, patients, and clients, all of which were identified in this study as best practices.

Positive organizational values were identified as the third contributing facilitator, which occurs through the establishment of organizational systems and processes and a patient-centered philosophy. Organizational leaders have the responsibility and the opportunity to include all four key facilitators by tapping into the contributions of other facilitators or building blocks for success in quality, resident-centered care.

The reader is encouraged to view from the study, results of what not to do to promote associate satisfaction and perception of quality care through the list of 19 barriers or detractors of care. Many of the barrier themes that emerged could be considered as symptoms of a non-supportive or "condescending" management style, the opposite spectrum of a positive, supportive leadership style.

\subsection{Limitations and Future Research}

The present study provided an extensive systematic review for the facilitators and barriers of the promotion of associate satisfaction of recent literature in long-term care facilities. Although the study met the objectives of identifying useful information relative to facilitators to further promote engagement and satisfaction and suggests the best practices for administrators, limitations existed in the present study. Our study did not categorize or quantify the types of long-term settings with each article review. This was beyond the scope of our study. From a counter perspective, not categorizing the settings lends itself to the generalizability of the results in a variety of long-term settings, including nursing homes, assisted living, community settings providing day services, and other service companies. In addition, our study did not collapse all facilitator and barrier themes, which could also be considered a limitation. Some of the themes could have been considered as sub-components of a broader theme. The reviewers set out to identify as many facilitators and barriers so as to lead to as many insights on best practices and systems to promote associate satisfaction, ultimately leading to resident and family satisfaction.

The current study was qualitative in methodology and although the articles themselves and the authors considered relationships, an opportunity exists to further quantify the relationships between facilitators and barriers. One would speculate that administrators and leaders using positive supportive leadership, creating a culture based on positive organizational values, empowering associates, and providing support mechanisms for employees will decrease the likelihood and influence of detractors or barriers such as condescending management styles, high job demands, and lack of self-empowerment. With that said, the current study did not quantify the relationship of the themes or study the correlation or regression of the themes. Thus, the results of this study provide opportunities for such studies in the future, relating to the strength of the relationship between organizational leadership characteristics and associates' capabilities and motivation.

A related limitation of the current study is that the authors did not have access to specific associate satisfaction data to make further discoveries on the significance of relationships of various themes within the data. Herein lies a future opportunity for additional studies. 


\section{Conclusions}

This study resulted in outlining key components to set in place for the promotion of associate satisfaction. The single most important facilitator of associate satisfaction was establishing supportive leadership, followed by empowering and developing employees, and establishing positive organizational values and support mechanisms. From the opposite perspective, administrators and managers using a condescending management style, setting high job demands, not supporting work-life balance or employees' self-care, and not providing adequate training to staff on how best to care for the medically complex clients promotes dissatisfaction in their associates. Administrators and leaders have the opportunity to utilize and grow the best practices in order to engage their associates, ultimately increasing the perception of the quality of care for their clients and residents. All of the considerations in this study have been become even more critical in the current situation with fighting the Covid-19 pandemic.

Author Contributions: The authors contributed to this research project through the following: Conceptualization, K.L. and M.M.; research project direction, administration, and management-K.L.; assistance with research supervision-M.M.; methodology, M.M.; literature review, consensus process meetings, theme analysis, validation, and formal analysis, K.L., M.M., J.F., L.F. and L.B.; creation of figures and Table 2-J.F.; creation of Table 1-L.F.; writing—original draft preparation, K.L., M.M. and J.F.; writing-review and editing, J.F., L.F., M.M., K.L. and L.B. All authors have read and agreed to the published version of the manuscript.

Funding: This research received no external funding.

Acknowledgments: Clemens Scott Kruse served as resource on the Systematic Literature Review methodology. The research team appreciates the methodology and resources provided by Kruse.

Conflicts of Interest: The authors declare no conflict of interest. 


\section{Appendix A}

Table A1. Summary of articles.

\begin{tabular}{|c|c|c|c|c|c|c|}
\hline Author Last Name/Year & Objective & Sample/Settings & Study Design and Comparison/Analytical Tool & Key Findings & $\mathrm{F} / \mathbf{B}^{1}$ & Theme \\
\hline Aloisio/2019 [22] & $\begin{array}{l}\text { To identify individual and } \\
\text { organizational predictors of job } \\
\text { satisfaction of managers in } \\
\text { long-term care (LTC) facilitities. }\end{array}$ & $\begin{array}{l}168 \text { managers from } 76 \text { LTC } \\
\text { homes in three Canadian } \\
\text { provinces. }\end{array}$ & $\begin{array}{l}\text { Michigan Organizational Assessment } \\
\text { Questionnaire Job Satisfaction Subscale was used } \\
\text { to measure job satisfaction. Represented secondary } \\
\text { analysis of data from Phase } 2 \text { of the Translating } \\
\text { Research in Elder Care Programme. }\end{array}$ & $\begin{array}{l}\text { This study identified one individual job } \\
\text { satisfaction predictor, high efficacy, and } \\
\text { three organizational job satisfaction } \\
\text { predictors, social capital, leadership, } \\
\text { and adequate orientation. }\end{array}$ & $\mathrm{F}$ & Positive Organizational Values \\
\hline \multirow[t]{2}{*}{ Perreira/2019 [76] } & \multirow{2}{*}{$\begin{array}{l}\text { Explore similarities and differences } \\
\text { in the work psychology of health } \\
\text { service workers employed in LTC } \\
\text { and home and community care } \\
\text { settings. }\end{array}$} & \multirow{2}{*}{$\begin{array}{l}276 \text { LTC employees and } 184 \\
\text { home health service } \\
\text { employees. }\end{array}$} & \multirow[t]{2}{*}{$\begin{array}{l}\text { A survey was used to collect data. Path analyses } \\
\text { and descriptive statistics were conducted. }\end{array}$} & $\begin{array}{l}\text { This study found that a positive work } \\
\text { environment promotes job satisfaction. }\end{array}$ & $\mathrm{F}$ & $\begin{array}{l}\text { Enjoyment of Relationships with } \\
\text { Patients }\end{array}$ \\
\hline & & & & $\begin{array}{l}\text { A low perception of support and } \\
\text { tension between facilities and } \\
\text { healthcare service workers were found } \\
\text { to be barriers to job satisfaction. }\end{array}$ & B & High Coworker Conflicts \\
\hline Malagon-Aguilera/2019 [23] & $\begin{array}{l}\text { To analyze the sense of coherence } \\
\text { among RNs }{ }^{2} \text { and its relationship } \\
\text { with health and work engagement. }\end{array}$ & $\begin{array}{l}109 \text { Nurses working in an } \\
\text { LTC setting. }\end{array}$ & 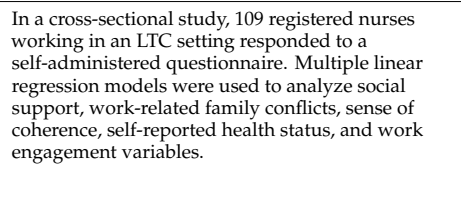 & $\begin{array}{l}\text { This study found that implementing a } \\
\text { program to implement a sense of } \\
\text { coherence (SOC) among nurses can } \\
\text { contribute to work engagement. A high } \\
\text { SOC was associated with adequate } \\
\text { socioeconomic level and social support } \\
\text { system. Managers providing social } \\
\text { support and assigning meaningful } \\
\text { tasks contributed to job satisfaction. }\end{array}$ & $\mathrm{F}$ & $\begin{array}{l}\text { Positive Organizational Values, Social } \\
\text { Support Mechanisms, and Supportive } \\
\text { Leadership and Management }\end{array}$ \\
\hline \multirow[t]{2}{*}{ Escrig-Pinol/2019 [24] } & \multirow[t]{2}{*}{$\begin{array}{l}\text { To gain a more refined } \\
\text { comprehension of the different } \\
\text { dimensions of the charge nurse } \\
\text { role as a central figure in the LTCFs } \\
{ }^{3} \text { analyzed. }\end{array}$} & \multirow[t]{2}{*}{$\begin{array}{l}10 \text { RN charge nurses from } \\
\text { five LTCFs in Ontario, } \\
\text { Canada. }\end{array}$} & \multirow[t]{2}{*}{$\begin{array}{l}\text { Data were collected via semi-structured interviews. } \\
\text { A combination of conventional and direct } \\
\text { qualitative content analyses was used. }\end{array}$} & $\begin{array}{l}\text { This study found the charge nurses } \\
\text { supervisisory skills to directly impact } \\
\text { team dynamics and relationships. } \\
\text { Professional coaching for charge nurses } \\
\text { in LTCS was found to enhance } \\
\text { work-life balance. Recognition for } \\
\text { responsibilitieis increases LTC charge } \\
\text { nurse job satisfaction. }\end{array}$ & $\mathrm{F}$ & $\begin{array}{l}\text { Supportive Leadership and } \\
\text { Management and Positive } \\
\text { Organizational Values }\end{array}$ \\
\hline & & & & $\begin{array}{l}\text { Undefined charge nurse roles and lack } \\
\text { of training were barriers to job } \\
\text { satisfaction. }\end{array}$ & B & $\begin{array}{l}\text { Lack of Access to Management, } \\
\text { Perception of Focus on Business } \\
\text { Aspects Interfering with Care, Lack of } \\
\text { Leadership Training, and Lack of } \\
\text { Training with Medically complex } \\
\text { patients }\end{array}$ \\
\hline \multirow[t]{2}{*}{ Rajamohan/2019 [75] } & \multirow[t]{2}{*}{$\begin{array}{l}\text { To understand the relationship } \\
\text { between staff and job satisfaction, } \\
\text { stress, turnover, and staff } \\
\text { outcomes in PCC NH }{ }^{4} \text { settings. }\end{array}$} & \multirow[t]{2}{*}{$\begin{array}{l}\text { Electronic research } \\
\text { databases between } 2000 \\
\text { and } 2015 \text {. }\end{array}$} & \multirow[t]{2}{*}{$\begin{array}{l}\text { Review electronic research databases published } \\
\text { between 2000 and } 2015 \text {. Cohen-Mansfield's } \\
\text { comprehensive occupational stress model was used } \\
\text { to analyze the relationshipi between job satisfaction, } \\
\text { stress, turnover, and staff outcomes in PCC NH } \\
\text { settings. }\end{array}$} & $\begin{array}{l}\text { This study identified providing patient } \\
\text { centered cara and integrating the } \\
\text { patient centered care philosophy into } \\
\text { the mission and vision of the } \\
\text { organization to facilitate job } \\
\text { satisfaction. }\end{array}$ & $\mathrm{F}$ & Patient-Centered Philosophy \\
\hline & & & & $\begin{array}{l}\text { Failure to understand patient-centered } \\
\text { care philososphy and failureo of } \\
\text { leadership to support employees in } \\
\text { daily activities were barriers to job } \\
\text { satisfaction. }\end{array}$ & B & $\begin{array}{l}\text { Lack of Training with Medically } \\
\text { Complex Patients, and Perception of } \\
\text { Focus on Business Aspects Interfering } \\
\text { with Care }\end{array}$ \\
\hline
\end{tabular}


Table A1. Cont.

\begin{tabular}{|c|c|c|c|c|c|c|}
\hline Author Last Name/Year & Objective & Sample/Settings & Study Design and Comparison/Analytical Tool & Key Findings & $\mathrm{F} / \mathbf{B}^{1}$ & Theme \\
\hline Jirkovská/2019 [81] & $\begin{array}{l}\text { To verify the Effort-Reward } \\
\text { Imbalanne (ERI) model, which } \\
\text { serves as a concept to map } \\
\text { workplace stress on professional } \\
\text { caregivers. }\end{array}$ & $\begin{array}{l}265 \text { Czech professionals in } \\
12 \text { facilities providing } \\
\text { health and social care } \\
\text { services for the elderly. }\end{array}$ & $\begin{array}{l}\text { The verification of the ERI model along with } \\
\text { well-being was conducted on the sample. }\end{array}$ & $\begin{array}{l}\text { This article suggests that a barrier of job } \\
\text { satisfaction is the challenge of } \\
\text { transforming from a traditional care } \\
\text { culture to a patient-centered care } \\
\text { culture. }\end{array}$ & $\mathrm{B}$ & Business Aspects Interfering with Care \\
\hline \multirow[t]{2}{*}{$\mathrm{Kim} / 2019$ [34] } & \multirow[t]{2}{*}{$\begin{array}{l}\text { To examine the efforts of social } \\
\text { support, job autonomy, and job } \\
\text { satisfaction on burnout among } \\
\text { LTC workers }\end{array}$} & \multirow[t]{2}{*}{$\begin{array}{l}170 \text { workers across } 23 \\
\text { agencies which } \\
\text { administrate LTCF in } \\
\text { Hawaii. }\end{array}$} & \multirow{2}{*}{$\begin{array}{l}\text { A convenience sampling method was used to select } \\
\text { participants from } 23 \text { agencies which administrate } \\
\text { LTCF. The Maslach Burnout Inventory was used to } \\
\text { measure burnout level. Job satisfaction was } \\
\text { measured using the current job satisfaction scale by } \\
\text { Kobiyama. Social support was measured using a } \\
\text { tool by Poulin and Walter. Descriptive statistics } \\
\text { and bivariate correlations were used to describe the } \\
\text { sample and to evaluate possible correlations. A } \\
\text { multiple regression analysis was performed to } \\
\text { study the effects of major independent variables on } \\
\text { burnout controlling for sociodemographic } \\
\text { variables. }\end{array}$} & $\begin{array}{l}\text { This study found that a supportive } \\
\text { work environment, social support, and } \\
\text { a sense of belonging and support from } \\
\text { management was key. }\end{array}$ & $\mathrm{F}$ & $\begin{array}{l}\text { Social Support Mechanisms, Social } \\
\text { Support Mechanisms, and Supportive } \\
\text { Leadership and Management }\end{array}$ \\
\hline & & & & $\begin{array}{l}\text { Lower social support, lower job } \\
\text { autonomy, lower administrative } \\
\text { support, and a sense of isolation were } \\
\text { barriers to job satisfaction. }\end{array}$ & $\mathrm{B}$ & $\begin{array}{l}\text { High Coworker Conflicts and } \\
\text { Condescending Management Style }\end{array}$ \\
\hline Kusmaul/2019 [60] & $\begin{array}{l}\text { Identify factors nursing homes can } \\
\text { adjust to improve culture for } \\
\mathrm{CNAs}^{5} \text { and residents. }\end{array}$ & $\begin{array}{l}106 \text { CNAs employed in } 3 \\
\text { LTCF. }\end{array}$ & $\begin{array}{l}\text { A secondary analysis of data gathered from a } \\
\text { multi-component paper survey of CNAs employed } \\
\text { in LTC. Used results from the Nursing Home } \\
\text { survey on Patient Safety Culture and primary shift, } \\
\text { type of unit, and years as a CNA to identify } \\
\text { modifiable characteristics that would explain } \\
\text { variability in the patient safety culture perceptions. }\end{array}$ & $\begin{array}{l}\text { CNAs perception of organizational } \\
\text { culture change contributed to job } \\
\text { satisfaction. }\end{array}$ & $\mathrm{F}$ & Capable Motivated Employees \\
\hline Rao/2019 [37] & $\begin{array}{l}\text { Identify the conditions in which } \\
\text { the impact of hospital nurse } \\
\text { staffing, nurse education, and } \\
\text { work environment are associated } \\
\text { with patient outcomes. }\end{array}$ & $\begin{array}{l}1,262,120 \text { general, } \\
\text { orthopedic, and vascular } \\
\text { surgery patients, and a } \\
\text { random sample of } 39,038 \\
\text { hospital staff nurses across } \\
665 \text { hospitals in four large } \\
\text { states. }\end{array}$ & $\begin{array}{l}\text { 30-day inpatient mortality and failure-to-rescue } \\
\text { were the measured outcomes. }\end{array}$ & $\begin{array}{l}\text { Higher professional support and } \\
\text { support from colleagues were found to } \\
\text { be facilitators to job satisfaction. }\end{array}$ & $\mathrm{F}$ & $\begin{array}{l}\text { Career/Professional Development and } \\
\text { Supportive Leadership and } \\
\text { Management }\end{array}$ \\
\hline Desveaux/2019 [52] & $\begin{array}{l}\text { To qualitatively determine } \\
\text { whether, how, and why an } \\
\text { academic detailing intervention } \\
\text { could improve evidence utpake, } \\
\text { and to identify changes that } \\
\text { occurred to advise outcomes for } \\
\text { quantitative evaluation. }\end{array}$ & $\begin{array}{l}11 \text { clinical and } \\
\text { administrative leaders, } 10 \\
\text { physicians, } 6 \text { direct care } \\
\text { providers, and } 2 \\
\text { pharmacists across } 13 \\
\text { nursing homes. }\end{array}$ & $\begin{array}{l}\text { A qualitative evaluation of } 29 \text { interviews with } \\
\text { nursing home staff, which were analyzed using the } \\
\text { framework method. }\end{array}$ & $\begin{array}{l}\text { A flexible approach, active knowledge } \\
\text { dissemination, and in-person } \\
\text { engagement are key components } \\
\text { required to drive change. }\end{array}$ & $\mathrm{F}$ & Capable and Motivated Employees \\
\hline Hartmann/2018 [73] & To improve resident engagement. & $\begin{array}{l}\text { Six Veterans Health } \\
\text { Administration nursing } \\
\text { homes. }\end{array}$ & $\begin{array}{l}\text { A mixed-methods study. The intervention was } \\
\text { implemented by using evidence-based tactics for } \\
\text { implementing quality improvement and combining } \\
\text { CLC-based staff facilitation with researcher-led } \\
\text { facilitation. Intervention success was assessed via } \\
\text { structured observations and resident and staff } \\
\text { surveys collected pre- and post-intervention. }\end{array}$ & $\begin{array}{l}\text { The study found that staff job } \\
\text { satisfaction was related to positive } \\
\text { meaningful engagements with } \\
\text { residents and professional } \\
\text { development opportunities. }\end{array}$ & $\mathrm{F}$ & $\begin{array}{l}\text { Patient-Centered Philosophy and } \\
\text { Career/Professional Development }\end{array}$ \\
\hline
\end{tabular}


Table A1. Cont.

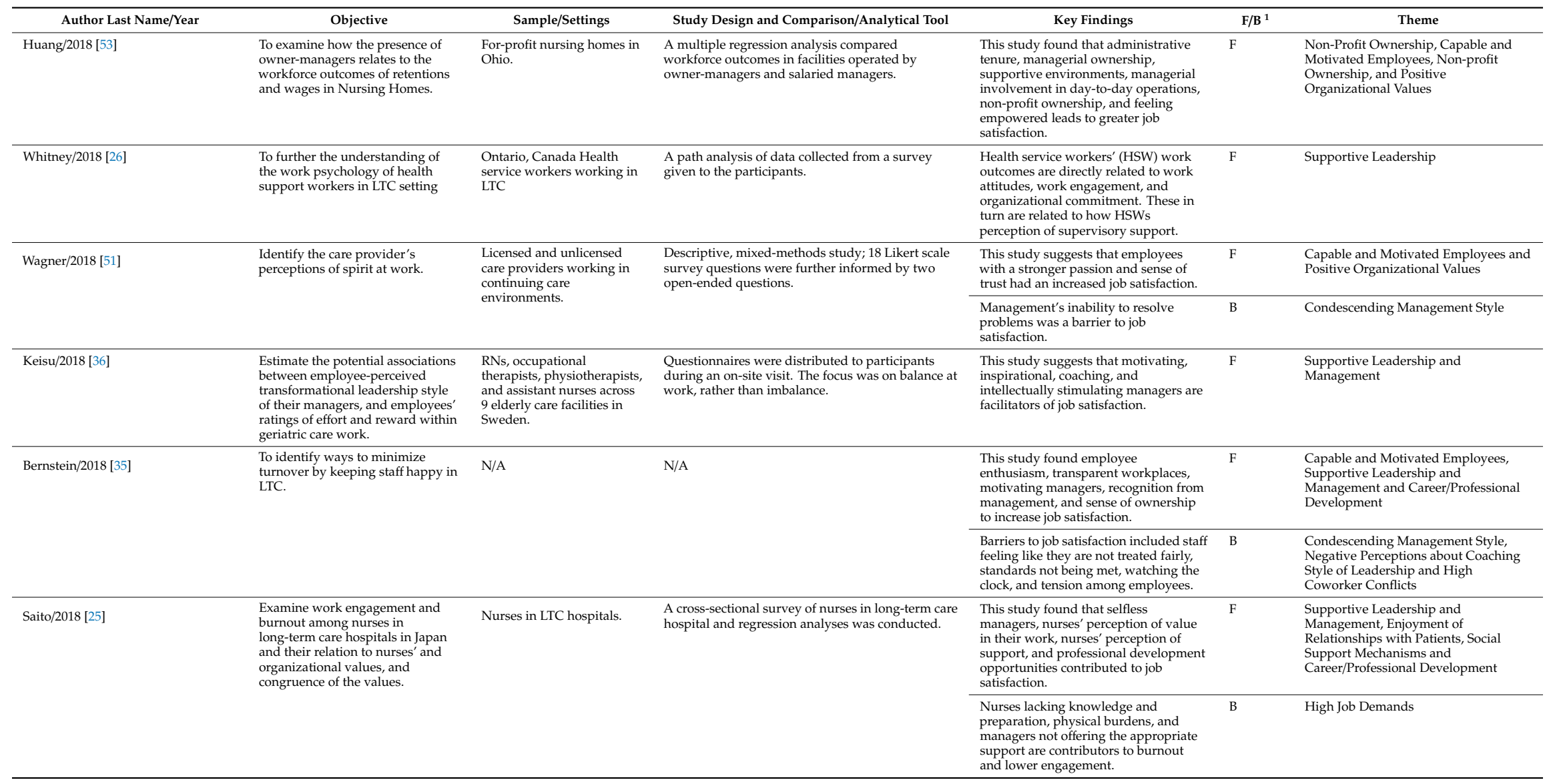


Table A1. Cont.

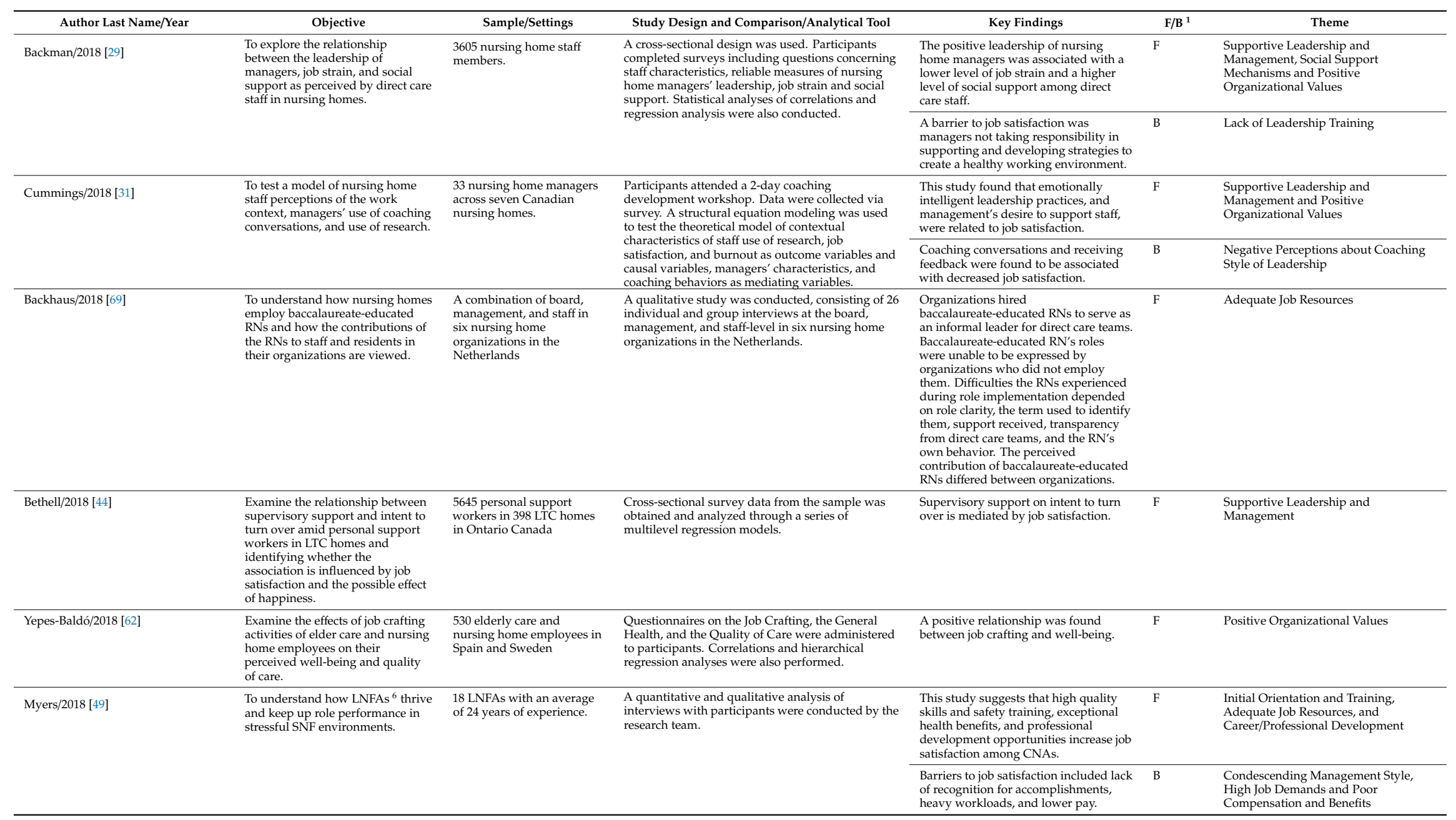


Table A1. Cont.

\begin{tabular}{|c|c|c|c|c|c|c|}
\hline Author Last Name/Year & Objective & Sample/Settings & Study Design and Comparison/Analytical Tool & Key Findings & $\mathrm{F} / \mathbf{B}^{1}$ & Theme \\
\hline Berridge/2018 [55] & $\begin{array}{l}\text { Examine whether staff } \\
\text { empowerment practices common } \\
\text { to nursing home culture change } \\
\text { are associated with CNA retention }\end{array}$ & $\begin{array}{l}2034 \text { nursing home } \\
\text { administrators }\end{array}$ & $\begin{array}{l}\text { Ordered logistic regression was used and data from } \\
2034 \text { nursing home administrators from a national } \\
\text { nursing home survey was analyzed. }\end{array}$ & $\begin{array}{l}\text { A high staff empowerment practice } \\
\text { score and greater CNA empowerment } \\
\text { opportunities were positively } \\
\text { associated with greater retention. }\end{array}$ & $\mathrm{F}$ & $\begin{array}{l}\text { Capable and Motivated Employees, } \\
\text { Adequate Resources to Do the Job and } \\
\text { Non-Profit Ownership }\end{array}$ \\
\hline \multirow[t]{2}{*}{ Matthews/2017 [27] } & \multirow{2}{*}{$\begin{array}{l}\text { To examine the quality of } \\
\text { manager-subordinate } \\
\text { relationships susing } \\
\text { Leader-Member Exchange Theory } \\
\text { (LMX) as a predictor to turnover } \\
\text { among low-wage earners in the } \\
\text { LTC environment. }\end{array}$} & \multirow[t]{2}{*}{$\begin{array}{l}\text { Participants were from a } \\
\text { large vertically integrated } \\
\text { southeastern LTC } \\
\text { organization. }\end{array}$} & \multirow[t]{2}{*}{$\begin{array}{l}\text { A cross-sectional method was used to gather } \\
\text { survey data over two periods. At time one, LMX, } \\
\text { demographic information and job satisfaction was } \\
\text { measured. At time two, turnover was measured. }\end{array}$} & $\begin{array}{l}\text { This study suggests teamwork, support } \\
\text { systems, versatility of foreigners, } \\
\text { adequate work time, and working for } \\
\text { larger organizations are associated with } \\
\text { a higher job satisfaction. }\end{array}$ & $\mathrm{F}$ & $\begin{array}{l}\text { Capable and Motivated Employees, } \\
\text { Social Support Mechanisms and } \\
\text { Adequate Job Resources }\end{array}$ \\
\hline & & & & $\begin{array}{l}\text { Poor resource management and an } \\
\text { unclear base pay amount are barriers to } \\
\text { job satisfaction. }\end{array}$ & B & $\begin{array}{l}\text { High Job Demand sand Poor Benefits } \\
\text { and Compensation }\end{array}$ \\
\hline \multirow[t]{2}{*}{ Doran/2017 [30] } & \multirow[t]{2}{*}{$\begin{array}{l}\text { Examine the intrapersonal, } \\
\text { interpersonal, and organizational } \\
\text { factors that predicted job } \\
\text { satisfaction for LTC employees }\end{array}$} & \multirow[t]{2}{*}{ Long-term care employees. } & \multirow[t]{2}{*}{$\begin{array}{l}\text { A forced linear regression model was used, while } \\
\text { controlling for age and job title, higher physical } \\
\text { activity levels, fewer symptoms of depression, } \\
\text { stress, and/or anxiety, less back pain, stronger } \\
\text { social support, and reports of low work demands } \\
\text { were assessed. }\end{array}$} & $\begin{array}{l}\text { The study found that the main factor } \\
\text { associated with job satisfaction was } \\
\text { mood, followed by interventions to } \\
\text { increase employees coping } \\
\text { mechanisms and receiving affirmation } \\
\text { from management. }\end{array}$ & $\mathrm{F}$ & $\begin{array}{l}\text { Capable and Motivated Employees, } \\
\text { Social Support Mechanisms and } \\
\text { Supportive Leadership and } \\
\text { Management }\end{array}$ \\
\hline & & & & $\begin{array}{l}\text { Barriers to job satisfaction included } \\
\text { short lunch breaks and minimal access } \\
\text { to nutritious meals. }\end{array}$ & B & Lack of Self-Care \\
\hline \multirow[t]{2}{*}{ Pung/2017 [68] } & \multirow{2}{*}{$\begin{array}{l}\text { To examine elements of job } \\
\text { satisfaction, their demands of } \\
\text { immigration score, explore any } \\
\text { relationship between job } \\
\text { satisfaction and demands of } \\
\text { immigration, and determine the } \\
\text { predictors of job satitefaction } \\
\text { among international nursing staff } \\
\text { working in LTC. }\end{array}$} & \multirow[t]{2}{*}{$\begin{array}{l}\text { International nursing staff } \\
\text { group, including those who } \\
\text { are non-Singaporean, } \\
\text { worked a minimum of one } \\
\text { year, and nursing staff who } \\
\text { provided direct patient care. }\end{array}$} & \multirow[t]{2}{*}{$\begin{array}{l}\text { A cross-sectional design was used, and participants } \\
\text { were chosen using a convenience-sampling } \\
\text { technique. }\end{array}$} & $\begin{array}{l}\text { This study found a positive workplace } \\
\text { climate, ,omprehenensive orientation } \\
\text { programs, and having the proper } \\
\text { resources to succeed were pindicators of } \\
\text { job satisfaction. }\end{array}$ & $\mathrm{F}$ & $\begin{array}{l}\text { Initial Orientation and Training, Social } \\
\text { Support Mechanisms, and Adequate } \\
\text { Job Resources }\end{array}$ \\
\hline & & & & $\begin{array}{l}\text { A barrier of job satisfaction is the lack } \\
\text { of understanding on the migration } \\
\text { demands of nurses and job satisfaction. }\end{array}$ & B & $\begin{array}{l}\text { Prohibitive Environmental } \\
\text { Characteristics }\end{array}$ \\
\hline Harding/2017 [43] & $\begin{array}{l}\text { To determine why staff in care } \\
\text { settings are unhappy and } \\
\text { understand the benefits of a } \\
\text { happier staff. }\end{array}$ & $\begin{array}{l}\text { Long-term care settings and } \\
\text { employees in the United } \\
\text { Kingdom. }\end{array}$ & $\begin{array}{l}\text { Observations from field experts were included in } \\
\text { the study. }\end{array}$ & $\begin{array}{l}\text { A barrier to job satisfaction was the } \\
\text { feeling of the inability to complete tasks } \\
\text { in each time frame. }\end{array}$ & B & High Job Demands and Stress \\
\hline Boscart/2017 [74] & $\begin{array}{l}\text { Changing the impact of nursing } \\
\text { assistants' education in seniors' } \\
\text { care by implementing the Living } \\
\text { Classroom (LC) approach. }\end{array}$ & $\begin{array}{l}\text { A Canadian college and } \\
\text { nursing home group. }\end{array}$ & $\begin{array}{l}\text { A collaborative approach to integrated learning } \\
\text { was conducted where nursing assistant students, } \\
\text { college faculty, NH teams, residents, and families } \\
\text { engage learning together. This approach placed the } \\
\text { studuent in the nursing home where knowledge, } \\
\text { team dynamics, behaviors, relationships, and } \\
\text { inter-professional practices are modeled. }\end{array}$ & $\begin{array}{l}\text { Nursing assistant students were highly } \\
\text { satisfied with the LC and intention to } \\
\text { seek employment in nursing homes } \\
\text { have increased. Nursing home teams, } \\
\text { residents, and families exhibitited } \\
\text { positive attitudes towards educating } \\
\text { students via LC. }\end{array}$ & $\mathrm{F}$ & Initial Orientation and Training \\
\hline \multirow[t]{2}{*}{ Chamberlain/2017 [54] } & \multirow[t]{2}{*}{$\begin{array}{l}\text { Examine organizational context, } \\
\text { care aide characteristics, and } \\
\text { frequency of dementia-related } \\
\text { resident responsive behaviors } \\
\text { associated with burnout. }\end{array}$} & \multirow[t]{2}{*}{$\begin{array}{l}1194 \text { care aides from } 30 \\
\text { urban nursing homes in } \\
\text { Canada. }\end{array}$} & \multirow{2}{*}{$\begin{array}{l}\text { A mixed-effects regression analysis was used to } \\
\text { assess care aide characteristics, dementia-related } \\
\text { responsive behaviors, unit and facility } \\
\text { characteristics, and organizational context } \\
\text { predictors of care aide burnout. Burnout was } \\
\text { measured using the Maslach Burnout Inventory } \\
\text { form. }\end{array}$} & $\begin{array}{l}\text { Unit culture and environmental } \\
\text { resources were predictors of } \\
\text { professional efficacy, which was } \\
\text { associated with increased care aide job } \\
\text { satisfaction. }\end{array}$ & $\mathrm{F}$ & $\begin{array}{l}\text { Positive Organizational Values, } \\
\text { Capable, and Motivated Employees } \\
\text { and Adequate Job Resources }\end{array}$ \\
\hline & & & & $\begin{array}{l}\text { Predictors of emotional exhaustion } \\
\text { included English as a second language, } \\
\text { medium facility size, organizational } \\
\text { slack-staff, organizational slack-space, } \\
\text { personal health, and dementia-related } \\
\text { behaviors. }\end{array}$ & B & $\begin{array}{l}\text { Prohibitive Environmental } \\
\text { Characteristics, Lack of Self-Care }\end{array}$ \\
\hline
\end{tabular}


Table A1. Cont.

\begin{tabular}{|c|c|c|c|c|c|c|}
\hline Author Last Name/Year & Objective & Sample/Settings & Study Design and Comparison/Analytical Tool & Key Findings & $F / \mathbf{B}^{1}$ & Theme \\
\hline \multirow[t]{2}{*}{ Elliott/2017 [38] } & \multirow{2}{*}{$\begin{array}{l}\text { To examine an expanded } \\
\text { demand-control-support model } \\
\text { that included justice perceptions to } \\
\text { determine its impact on multiple } \\
\text { types of pyschological and } \\
\text { organizational well-being } \\
\text { outcomes. }\end{array}$} & \multirow[t]{2}{*}{173 aged care nurses. } & \multirow[t]{2}{*}{$\begin{array}{l}\text { A self-report survey was used to collect and } \\
\text { analyze data using hierarchical multiple regression. }\end{array}$} & $\begin{array}{l}\text { This study found job control, high } \\
\text { quality training, exceptional health } \\
\text { benefits, and professional develoment } \\
\text { opportunities increase job satisfaction. }\end{array}$ & $\mathrm{F}$ & $\begin{array}{l}\text { Adequate Job Resources, Adequate Job } \\
\text { Resources, Initial Orientation and } \\
\text { Training, Adequate Job Resources and } \\
\text { Career/Professional Development }\end{array}$ \\
\hline & & & & $\begin{array}{l}\text { Barriers to job satisfaction included } \\
\text { staffing shortages, lack of respect and } \\
\text { recognition, low pay, and heavy } \\
\text { workload. }\end{array}$ & B & $\begin{array}{l}\text { High Job Demands, Condescending } \\
\text { Management Style, High Job Demands } \\
\text { and Poor Compensation and Benefits }\end{array}$ \\
\hline Adams/2017 [45] & $\begin{array}{l}\text { To analyze staff perceptions of } \\
\text { skills required and to identify } \\
\text { discrepancies in job satisfaction, } \\
\text { motivation, and characteristics of } \\
\text { staff working in traditional } \\
\text { nursing home environments and } \\
\text { patient-centered small-scale } \\
\text { environments. }\end{array}$ & $\begin{array}{l}\text { A secondary data analysis } \\
\text { was conducted from a } \\
\text { previous, larger study } \\
\text { testing the effects of } \\
\text { small-scale living (Verbeek } \\
\text { et al., 2009); } 138 \text { staff } \\
\text { members were included. }\end{array}$ & $\begin{array}{l}\text { A questionnaire was used to gather data on the job } \\
\text { satisfaction, motivation, and job characteristics of } \\
\text { nursing staff working in small-scale and traditional } \\
\text { care environments. Descriptive statistics were used } \\
\text { to analyze data, and multilininear regression analysis } \\
\text { was used to test the differences between job } \\
\text { satisfaction, motivation, and job characteristics. }\end{array}$ & $\begin{array}{l}\text { In small-scale nursing homes, job } \\
\text { satisfaction and job motivation were } \\
\text { siginicicantly higher compared to those } \\
\text { in traditional nursing homes. Job } \\
\text { attonomy and social support were also } \\
\text { higher, while job demands were lower } \\
\text { in small-scale nursing homes. Social } \\
\text { support was the most notable predictor } \\
\text { of job motivation and job satisfaction in } \\
\text { both types of nursing home. } \\
\text { Employee patience and motivation was } \\
\text { a factor when determining cases where } \\
\text { there was an intention to switch care } \\
\text { environments. }\end{array}$ & $\mathrm{F}$ & $\begin{array}{l}\text { Adequate Job Resources, Social } \\
\text { Support Mechanisms, Capable and } \\
\text { Motivated Employees and Supportive } \\
\text { Leadership and Management }\end{array}$ \\
\hline \multirow[t]{2}{*}{ Tong/2017 [46] } & \multirow{2}{*}{$\begin{array}{l}\text { To examine the frequency of } \\
\text { mobbing in nursing homes and its } \\
\text { relationships with care workers' } \\
\text { health status, job satisfaction, and } \\
\text { intention to leave, and to examine } \\
\text { the work environment as a } \\
\text { contributing factor to mobbing. }\end{array}$} & \multirow{2}{*}{$\begin{array}{l}162 \text { nursing homes in } \\
\text { Switzerland with } 20 \text { or } \\
\text { more beds, including } 5311 \\
\text { care workers. }\end{array}$} & \multirow{2}{*}{$\begin{array}{l}\text { A cross-sectional, multi-center sub-study of the } \\
\text { Swiss Nursing Homes Human Resource Project } \\
\text { (SHURP). Generalized estimation equations were } \\
\text { used to assess the relationships between mobbing } \\
\text { and care workers' job satisfaction, health status, } \\
\text { desire to leave, and association of work } \\
\text { environment factors with mobbing. }\end{array}$} & $\begin{array}{l}\text { This study found that supportive } \\
\text { leadership and open communication } \\
\text { contributed to job satisfaction. }\end{array}$ & $\mathrm{F}$ & $\begin{array}{l}\text { Supportive Leadership and } \\
\text { Management }\end{array}$ \\
\hline & & & & $\begin{array}{l}\text { Employees affected by mobbing felt } \\
\text { leadership was not supportive, felt } \\
\text { isolated, and experienced a higher } \\
\text { workload, which lead to job } \\
\text { dissatisfaction. }\end{array}$ & B & $\begin{array}{l}\text { High Job Demands, High Coworker } \\
\text { Conflicts and Condescending } \\
\text { Management Style }\end{array}$ \\
\hline Chamberlain/2016 [32] & $\begin{array}{l}\text { To determine the organizational } \\
\text { and individual variables } \\
\text { associated with job satisfaction in } \\
\text { care aides. }\end{array}$ & $\begin{array}{l}1224 \text { care aides from } 30 \\
\text { LTCF homes in three } \\
\text { Western Canadian } \\
\text { provinces. }\end{array}$ & $\begin{array}{l}\text { Participants reported job satisfaction and } \\
\text { perception of the work environment via survey. A } \\
\text { hierarchical, mixed-effects ordered logistic } \\
\text { regression was used to demonstrate the oodds of } \\
\text { care aide job satisfaction for individual, care unit } \\
\text { and facility factors. }\end{array}$ & $\begin{array}{l}\text { The barriers to job satisfaction were } \\
\text { emotional exhaustion and working in } \\
\text { Alzheimer's units. }\end{array}$ & $\mathrm{B}$ & $\begin{array}{l}\text { Patient Complexity, Prohibitive } \\
\text { Environmental Characteristics and } \\
\text { Lack of Self-Care }\end{array}$ \\
\hline
\end{tabular}


Table A1. Cont.

\begin{tabular}{|c|c|c|c|c|c|c|}
\hline Author Last Name/Year & Objective & Sample/Settings & Study Design and Comparison/Analytical Tool & Key Findings & $F / \mathbf{B}^{1}$ & Theme \\
\hline \multirow[t]{2}{*}{ Schwendimann/2016 [47] } & \multirow[t]{2}{*}{$\begin{array}{l}\text { Describe job satisfaction among } \\
\text { care workers and to examine its } \\
\text { associations with work } \\
\text { environment factors, work } \\
\text { stressors, and health issues in } \\
\text { Swiss nursing homes. }\end{array}$} & \multirow[t]{2}{*}{$\begin{array}{l}162 \text { Swiss nursing homes } \\
\text { including } 4145 \text { care } \\
\text { workers. }\end{array}$} & \multirow[t]{2}{*}{$\begin{array}{l}\text { Care worker-reported job satisfaction was } \\
\text { measured with a single item. Explanatory variables } \\
\text { were assessed with established scales. Factors } \\
\text { related to ojob satisfaction were examined using } \\
\text { Generalized Estimating Equation models. }\end{array}$} & $\begin{array}{l}\text { This study found work environmental } \\
\text { factors, clear leadership, adequate } \\
\text { resources and staffing, supportive } \\
\text { leadership, and teamwork to contribute } \\
\text { to job satisfaction. }\end{array}$ & $\mathrm{F}$ & $\begin{array}{l}\text { Adequate Job Resources, Supportive } \\
\text { Leadership and Management and } \\
\text { Social Support Mechanisms }\end{array}$ \\
\hline & & & & $\begin{array}{l}\text { Job satisfaction decreased when } \\
\text { workplace conflict tincreased, during } \\
\text { emotional exhaustion, and when access } \\
\text { to managing decreased. }\end{array}$ & B & $\begin{array}{l}\text { High Coworker Conflicts, Lack of Self } \\
\text { Care and Lack of Access to } \\
\text { Management }\end{array}$ \\
\hline Wendsche/2016 [77] & $\begin{array}{l}\text { To investigate how two types of } \\
\text { care settings and types of } \\
\text { ownership of geriatric care } \\
\text { services influenced RNs intention } \\
\text { to change professions. } \\
\end{array}$ & $\begin{array}{l}304 \text { RNs working in } 78 \\
\text { different care units in } \\
\text { Germany. }\end{array}$ & $\begin{array}{l}\text { A cross-sectional study was conducted collecting } \\
\text { questionnaire data from RNs working in } 78 \text { care } \\
\text { units. }\end{array}$ & $\begin{array}{l}\text { This study found higher job demands, } \\
\text { working in for-profit environments, } \\
\text { and lack of fob control to decrease job } \\
\text { satisfaction. }\end{array}$ & B & $\begin{array}{l}\text { High Job Demands, Non-Profit } \\
\text { Ownership and Condensing } \\
\text { Management Style }\end{array}$ \\
\hline \multirow[t]{2}{*}{ Roen/2016 [28] } & \multirow[t]{2}{*}{$\begin{array}{l}\text { To examine the association } \\
\text { between patient-centered care and } \\
\text { organizational, staff and unit } \\
\text { characteristics in nursing homes }\end{array}$} & \multirow[t]{2}{*}{$\begin{array}{l}175 \text { nursing home staff in } \\
\text { Norway }\end{array}$} & \multirow[t]{2}{*}{$\begin{array}{l}\text { A survey was distributed including measures of } \\
\text { patient-centered care and questions concerning } \\
\text { staff characteristics and work-related psychosocial } \\
\text { elements. Association with patient-centered care } \\
\text { was analyzzed using multilievel linear regression } \\
\text { analyses. }\end{array}$} & $\begin{array}{l}\text { High levels of patient-centered care, a } \\
\text { patient-centered care work } \\
\text { environment, and supportive } \\
\text { leadership were associated with greater } \\
\text { job satisfaction. }\end{array}$ & $\mathrm{F}$ & $\begin{array}{l}\text { Patient-Centered Philosophy and } \\
\text { Supportive Leadership and } \\
\text { Management }\end{array}$ \\
\hline & & & & $\begin{array}{l}\text { A barrier to job satisfaction was lack of } \\
\text { managerial leadership. }\end{array}$ & B & Lack of Leadership Training \\
\hline Gray/2016 [48] & $\begin{array}{l}\text { Identify themes to potentially help } \\
\text { CNAs make meaning out of their } \\
\text { chosen career; thus, potentially } \\
\text { explaining increases in job } \\
\text { satisfaction among this group. }\end{array}$ & CNAs at three LTCFs. & $\begin{array}{l}\text { Focus groups were conducted with CNAs in the } \\
\text { three LTCFs. }\end{array}$ & $\begin{array}{l}\text { This study found strong teamwork, } \\
\text { perception of good work, making } \\
\text { positive impacts on patients' 'lives, } \\
\text { positive relationships with residents, } \\
\text { professional development } \\
\text { opportunities, and recognition by } \\
\text { leadership to result in high job } \\
\text { satisfaction. }\end{array}$ & $\mathrm{F}$ & $\begin{array}{l}\text { Positive Organizational Values, } \\
\text { Patient-Centered Philosophy, } \\
\text { Enjoyment of Relationships with } \\
\text { Patients, Supportive Leadership and } \\
\text { Management and Career/Professional } \\
\text { Development }\end{array}$ \\
\hline \multirow[t]{2}{*}{ der Zijpp/2016 [66] } & \multirow{2}{*}{$\begin{array}{l}\text { To describe the interaction } \\
\text { between managerial leaders and } \\
\text { internal facilitators (clinical leaders } \\
\text { acting as facilitators) and how this } \\
\text { enabled or hindered the facilitation } \\
\text { process of implementing urinary } \\
\text { incontinence guideleline } \\
\text { recommendations in a local } \\
\text { context in settings that provide } \\
\text { LTC to elderly individuals. }\end{array}$} & \multirow[t]{2}{*}{$\begin{array}{l}105 \text { managers and } 22 \\
\text { internal facilitators across } \\
\text { four European countries. }\end{array}$} & \multirow[t]{2}{*}{$\begin{array}{l}\text { Semi-structured interviews were conducted to } \\
\text { collect a realist evaluation process. An interpretive } \\
\text { data analysis unpacks interactions between } \\
\text { managerial leaders and internal facilitators. }\end{array}$} & $\begin{array}{l}\text { This study suggests that building } \\
\text { relationships, encouragement from } \\
\text { management, and a sense of being } \\
\text { valued promote job satisfaction. }\end{array}$ & $\mathrm{F}$ & Social Support Mechanisms \\
\hline & & & & $\begin{array}{l}\text { A lack of commitment from } \\
\text { management was a barrier to job } \\
\text { satisfaction. }\end{array}$ & B & Condescending Management Style \\
\hline
\end{tabular}


Table A1. Cont.

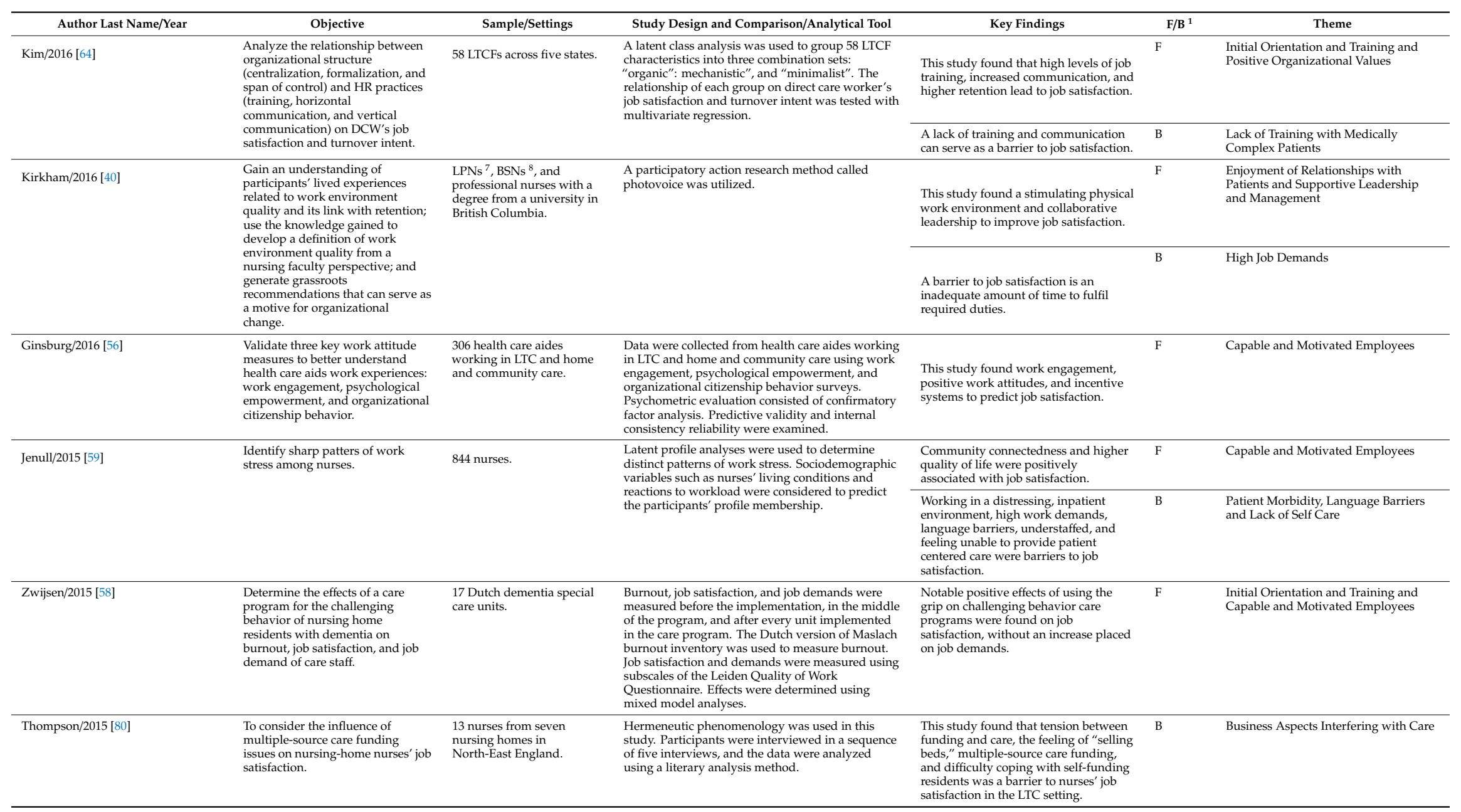


Table A1. Cont.

\begin{tabular}{|c|c|c|c|c|c|c|}
\hline Author Last Name/Year & Objective & Sample/Settings & Study Design and Comparison/Analytical Tool & Key Findings & $\mathrm{F} / \mathbf{B}^{1}$ & Theme \\
\hline \multirow[t]{2}{*}{ Binney/2015 [50] } & \multirow{2}{*}{$\begin{array}{l}\text { Explore the perceptions of work } \\
\text { engagement among RNs working } \\
\text { in LTC. }\end{array}$} & \multirow[t]{2}{*}{$\begin{array}{l}\text { Eight RNs in an LTCF in the } \\
\text { United States. }\end{array}$} & \multirow[t]{2}{*}{$\begin{array}{l}\text { Eight RNs in a LTCF in the United States served as } \\
\text { subjects in the study. }\end{array}$} & $\begin{array}{l}\text { Dedicated and committed nurses } \\
\text { increase job satisfaction. }\end{array}$ & $\mathrm{F}$ & Capable and Motivated Employees \\
\hline & & & & $\begin{array}{l}\text { High patient morality rates, increased } \\
\text { workloads, and stress were barriers to } \\
\text { job satisfaction. }\end{array}$ & B & Patient Morbidity \\
\hline \multirow[t]{2}{*}{ Knecht/2015 [39] } & \multirow[t]{2}{*}{$\begin{array}{l}\text { Examine the attributes of LTC } \\
\text { LPNs' job satisfaction and } \\
\text { dissatisfaction. }\end{array}$} & \multirow[t]{2}{*}{$\begin{array}{l}\text { 4-12 LPNs in six LTCFs in } \\
\text { Philadelphia. }\end{array}$} & \multirow{2}{*}{$\begin{array}{l}\text { A qualitative, } 90 \text { min focus group study was } \\
\text { conducted at each LTCF. Four to twelve LPNs in } \\
\text { each of the six focus groups participated in a focus } \\
\text { group session. Herzberg's motivation/hygienen } \\
\text { theory (1959) provided the basis for the framework } \\
\text { for the study. The focus group methodology } \\
\text { allowed for the utilization of the collective power } \\
\text { of individidual and group discussion, resulting in } \\
\text { ample data. Data analysis began after the first focus } \\
\text { group session was complete. Utilization of member } \\
\text { checks, expert verification, and maintenance of an } \\
\text { audit trail contributed to trustworthiness. }\end{array}$} & $\begin{array}{l}\text { This study found that work recognition } \\
\text { and feeling valued by residents' } \\
\text { families increased job satisfaction }\end{array}$ & $\mathrm{F}$ & $\begin{array}{l}\text { Supportive Leadership and } \\
\text { Management and Relationships with } \\
\text { Patients }\end{array}$ \\
\hline & & & & $\begin{array}{l}\text { Barriers to job satisfaction included } \\
\text { poor pay and poor performance not } \\
\text { being properly reprimanded by } \\
\text { management. }\end{array}$ & B & $\begin{array}{l}\text { Negative Perceptions about Coaching } \\
\text { Style of Leadership and Poor } \\
\text { Compensation and Benefits }\end{array}$ \\
\hline Smikle/2015 [57] & $\begin{array}{l}\text { To investigate why LTC employees } \\
\text { choose to stay and explore } \\
\text { retention strategies for LTC. }\end{array}$ & $\begin{array}{l}39 \text { LTC employees with } \\
10-34 \text {-year tenure rating. }\end{array}$ & $\begin{array}{l}\text { Participants participated in a single, individual } \\
\text { review. Stories relating to why employees chose to } \\
\text { stay were gathered. }\end{array}$ & $\begin{array}{l}\text { Facilitators to job satisfaction in this } \\
\text { study included involvement in the } \\
\text { organization, supportive and } \\
\text { compassionate leadership, sense of } \\
\text { connectedness, and professional } \\
\text { development opportunities. }\end{array}$ & $\mathrm{F}$ & $\begin{array}{l}\text { Capable and Motivated Employees, } \\
\text { Positive Organizational Values and } \\
\text { Career/Professional Development }\end{array}$ \\
\hline \multirow[t]{2}{*}{ Wallin/2015 [65] } & \multirow{2}{*}{$\begin{array}{l}\text { Investigate job strain and stress of } \\
\text { conscience among nurse asssistants } \\
\text { working in residential care and } \\
\text { explore associations with personal } \\
\text { and work-related aspects and } \\
\text { health complaints. }\end{array}$} & \multirow[t]{2}{*}{225 nursing assistants. } & \multirow{2}{*}{$\begin{array}{l}\text { Questionnaires to measure job strain, stress of } \\
\text { conscience, personal and work-related aspects of } \\
\text { health complaints were completeted by } 225 \text { nursing } \\
\text { assistants. Multiple linear regression analyses were } \\
\text { performed to compare high and low levels of job } \\
\text { strain and stress of conscience. }\end{array}$} & $\begin{array}{l}\text { Organizational and environmental } \\
\text { support were positively associated with } \\
\text { job satisfaction. }\end{array}$ & $\mathrm{F}$ & Social Support Mechanisms \\
\hline & & & & $\begin{array}{l}\text { Lack of education, poor leadership, } \\
\text { heavy workload, and lack of } \\
\text { opportunities to discuss difficult } \\
\text { situations were found to be barriers to } \\
\text { job satisfaction. }\end{array}$ & B & $\begin{array}{l}\text { Lack of Training with Medically } \\
\text { Complex Patients and High Job } \\
\text { Demands }\end{array}$ \\
\hline \multirow[t]{2}{*}{ Butler/2014 [71] } & \multirow[t]{2}{*}{$\begin{array}{l}\text { Explore determinants of longer job } \\
\text { tenure for home care aides. }\end{array}$} & \multirow[t]{2}{*}{261 home care aides. } & \multirow{2}{*}{$\begin{array}{l}\text { Mixed-method study. Home care aides were } \\
\text { followed for } 18 \text { months and completed two mail } \\
\text { surveys and one phone interview. }\end{array}$} & $\begin{array}{l}\text { The study found higher wages to be a } \\
\text { predicter of job satisfaction. }\end{array}$ & $\mathrm{F}$ & Adequate Job Resources \\
\hline & & & & $\begin{array}{l}\text { Lack of available hours, poor } \\
\text { compensastion, poor communication, } \\
\text { and difficultuly building relationships } \\
\text { with employing agency contributed to } \\
\text { a decrease in job satisfaction. }\end{array}$ & B & $\begin{array}{l}\text { High Job Demands and Condescending } \\
\text { Management Style }\end{array}$ \\
\hline
\end{tabular}


Table A1. Cont.

\begin{tabular}{|c|c|c|c|c|c|c|}
\hline Author Last Name/Year & Objective & Sample/Settings & Study Design and Comparison/Analytical Tool & Key Findings & $F / \mathbf{B}^{1}$ & Theme \\
\hline \multirow[t]{2}{*}{ Zhang/2014 [33] } & \multirow[t]{2}{*}{$\begin{array}{l}\text { Identify the relationships among } \\
\text { LTC employees' working } \\
\text { conditions, mental health, and } \\
\text { desire to leave. }\end{array}$} & \multirow[t]{2}{*}{$\begin{array}{l}1589 \text { employees from } 18 \\
\text { for-profit nursing homes }\end{array}$} & \multirow[t]{2}{*}{$\begin{array}{l}\text { This is a quantitative study. Data were collected via } \\
\text { selffadminisistered questionnaires from } 1589 \\
\text { for-profit nursing homes. The number of beneficial } \\
\text { job features was constructed via a working } \\
\text { condition index. }\end{array}$} & $\begin{array}{l}\text { This study found that healthy working } \\
\text { environments, strong interepersonal } \\
\text { relationships, coworker support, and } \\
\text { supervisor support contributed to job } \\
\text { satisfaction. }\end{array}$ & F & $\begin{array}{l}\text { Positive Organizational Values and } \\
\text { Supportive Leadership and } \\
\text { Management }\end{array}$ \\
\hline & & & & $\begin{array}{l}\text { Poor mental health was a barrier to job } \\
\text { satisfaction. }\end{array}$ & B & Lack of Self-Care \\
\hline Wendsche/2014 [63] & $\begin{array}{l}\text { Identify direct and indirect links } \\
\text { between geriatric care setting, rest } \\
\text { break organization, and registered } \\
\text { nurses' turnover assessed for one } \\
\text { year. }\end{array}$ & $\begin{array}{l}80 \text { nursing units within } 51 \\
\text { geriatric care services } \\
\text { employing } 597 \text { RNs in } \\
\text { Germany. }\end{array}$ & $\begin{array}{l}\text { Multimethod cross-sectional study was used to } \\
\text { assess nursing unites within geriatric care. }\end{array}$ & $\begin{array}{l}\text { This study found collective rest breaks } \\
\text { and working in non-profit facilities to } \\
\text { contribute to job satisfaction. }\end{array}$ & $\mathrm{F}$ & $\begin{array}{l}\text { Positive Organizational Values, } \\
\text { Non-Profit Ownership }\end{array}$ \\
\hline Willemse/2014 [70] & $\begin{array}{l}\text { Highlight the consequences of } \\
\text { small-scale care on staff's of } \\
\text { perceived job characteristics. }\end{array}$ & $\begin{array}{l}136 \text { Dutch dementia care } \\
\text { nursing homes with } 1327 \\
\text { residents and } 1147 \text { staff. }\end{array}$ & $\begin{array}{l}\text { Multilievel regression analyses were used to study } \\
\text { the relationship between two indicators of } \\
\text { small-scale care and staff's job characteristics. }\end{array}$ & $\begin{array}{l}\text { Nurses being assigned less } \\
\text { residents/patients had a positive effect } \\
\text { on job satisfaction in this study. }\end{array}$ & $\mathrm{F}$ & Adequate Job Resources \\
\hline \multirow[t]{2}{*}{ McGilton/2014 [72] } & \multirow[t]{2}{*}{$\begin{array}{l}\text { Understand factors that influence } \\
\text { nurses' intentions to continue } \\
\text { employment at their current job. }\end{array}$} & \multirow[t]{2}{*}{$\begin{array}{l}41 \text { LTC nurses in seven } \\
\text { nursing homes in Ontario, } \\
\text { Canada. }\end{array}$} & \multirow[t]{2}{*}{$\begin{array}{l}\text { Focus groups were conducted at the seven nursing } \\
\text { homes through focus groups, and the discussions } \\
\text { within the group were transcribed verbatim. } \\
\text { Themes for the groups were developed via directed } \\
\text { content analysis. }\end{array}$} & $\begin{array}{l}\text { This study found the development of } \\
\text { meaningful relationships with residents } \\
\text { and professional development } \\
\text { opportunities to promote job } \\
\text { satisfaction. }\end{array}$ & $\mathrm{F}$ & $\begin{array}{l}\text { Relationships with Patients and } \\
\text { Career/Professional Development }\end{array}$ \\
\hline & & & & $\begin{array}{l}\text { Regulations on role flexibility, } \\
\text { underfunded systems, and lack of } \\
\text { management support were barriers to } \\
\text { job satisfaction. }\end{array}$ & B & $\begin{array}{l}\text { High Job Demand sand Negative } \\
\text { Perceptions about Coaching Style of } \\
\text { Leadership }\end{array}$ \\
\hline Meyer/2014 [78] & $\begin{array}{l}\text { To follow rural CNAs in the US } \\
\text { one year after training to identify } \\
\text { retention and turnover in the LTC } \\
\text { setting, using CAN's perceptions } \\
\text { of the LTC work experience. }\end{array}$ & $\begin{array}{l}123 \text { CNAs from the United } \\
\text { States. }\end{array}$ & $\begin{array}{l}\text { A longitudinal survey design was used to track } \\
\text { CNAs completing training for one year. }\end{array}$ & $\begin{array}{l}\text { The first } 6 \text { months of employment most } \\
\text { impacted retention; } 53.7 \% \text { CNAs were } \\
\text { retained after one year; and the CNAs } \\
\text { leaving cited pay as being the number } \\
\text { one reason for leaving. }\end{array}$ & B & $\begin{array}{l}\text { High Job Demands and Poor Comp } \\
\text { and Benefits }\end{array}$ \\
\hline \multirow[t]{2}{*}{ McGilton/2014 [42] } & \multirow{2}{*}{$\begin{array}{l}\text { Describe the organizational, } \\
\text { unregulated nurse and resident } \\
\text { outcomes associated with effective } \\
\text { supervisory performance of } \\
\text { regulated nurses in LTC homes. }\end{array}$} & \multirow[t]{2}{*}{$\begin{array}{l}\text { Regulated nurses working } \\
\text { in LTC homes. }\end{array}$} & \multirow{2}{*}{$\begin{array}{l}\text { Six databases were utilized to gather articles } \\
\text { between } 2000 \text { and } 2015 \text {. Twenty-four articles were } \\
\text { selected, and an integrative interview was } \\
\text { performed. }\end{array}$} & $\begin{array}{l}\text { Nurse supervisor performance left } \\
\text { employees feeling empowered, } \\
\text { increasing job satisfaction. }\end{array}$ & $\mathrm{F}$ & $\begin{array}{l}\text { Supportive Leadership and } \\
\text { Management }\end{array}$ \\
\hline & & & & $\begin{array}{l}\text { Poor supervision over nurses was a } \\
\text { barrier to job satisfaction. }\end{array}$ & B & Condescending Management Style \\
\hline \multirow[t]{2}{*}{ Chu/2014 [41] } & \multirow{2}{*}{$\begin{array}{l}\text { Describe the relationship between } \\
\text { nursing staff turnover in LTC } \\
\text { homes and organizational factors } \\
\text { (i.e., leadership practices and } \\
\text { behaviors, supervisisory support, } \\
\text { burnout, job satisfaction and work } \\
\text { environment satisfaction). }\end{array}$} & \multirow[t]{2}{*}{ LTCF administrators. } & \multirow{2}{*}{$\begin{array}{l}\text { A stress process model was used. Surveys were } \\
\text { distributed to LTC administrators to measure } \\
\text { organizational factors and to regulated nurses to } \\
\text { measure sources of stress and workplace support; } \\
324 \text { surveys were used in a linear regression } \\
\text { analysis to examine factors related to high turnover } \\
\text { rates. }\end{array}$} & $\begin{array}{l}\text { This study identified greater support } \\
\text { from management, empowering work } \\
\text { environments, and employee assistance } \\
\text { programs as contributors to job } \\
\text { satisfaction. }\end{array}$ & F & $\begin{array}{l}\text { Supportive Leadership and } \\
\text { Management and Social Support } \\
\text { Mechanisms }\end{array}$ \\
\hline & & & & $\begin{array}{l}\text { Lack of supervisory support, poor } \\
\text { leadership, adminisistration turnover, } \\
\text { and poor work environments were } \\
\text { barriers to job satisfaction. }\end{array}$ & B & $\begin{array}{l}\text { Condescending Management Style by } \\
\text { Supervisor or Senior Leaders and Lack } \\
\text { of Access to Management }\end{array}$ \\
\hline
\end{tabular}


Table A1. Cont.

\begin{tabular}{|c|c|c|c|c|c|c|}
\hline Author Last Name/Year & Objective & Sample/Settings & Study Design and Comparison/Analytical Tool & Key Findings & $\mathrm{F} / \mathbf{B}^{1}$ & Theme \\
\hline \multirow[t]{2}{*}{ Киo/2014 [67] } & \multirow{2}{*}{$\begin{array}{l}\text { Explore the mediating effects of job } \\
\text { satisfaction on work stress and } \\
\text { turnover intention among LTC } \\
\text { nurses. }\end{array}$} & \multirow[t]{2}{*}{ LTC nurses in Taiwan. } & \multirow[t]{2}{*}{$\begin{array}{l}\text { The study used a cross-sectional survey and a } \\
\text { correlation design. Multistage linear regression } \\
\text { was utilized to test the mediation model. }\end{array}$} & $\begin{array}{l}\text { Low stress levels among LTC } \\
\text { employees lead to a higher job } \\
\text { satisfaction. }\end{array}$ & $\mathrm{F}$ & Social Support Mechanisms \\
\hline & & & & $\begin{array}{l}\text { Barriers to job satisfaction include high } \\
\text { stresss levels, unfair working hours, and } \\
\text { lack of supportive leadership. }\end{array}$ & B & High Job Demands \\
\hline Jungyoon/2014 [79] & $\begin{array}{l}\text { To examine the relationship } \\
\text { between organizational structure } \\
\text { and HR practices on job } \\
\text { satisfaction and turnover intent. }\end{array}$ & $\begin{array}{l}50 \text { LTC facilities across five } \\
\text { states. }\end{array}$ & $\begin{array}{l}\text { A latent class analysis was used to group facility } \\
\text { characteristics into three sets of combinations. A } \\
\text { multivariate regression was used to test the } \\
\text { relationship between groups on job satisfaction and } \\
\text { turnover intent. }\end{array}$ & $\begin{array}{l}\text { This study found low levels of job } \\
\text { training and communication to be } \\
\text { barriers to job satisfaction. }\end{array}$ & B & $\begin{array}{l}\text { Lack of Training with Medically } \\
\text { Complex Patients }\end{array}$ \\
\hline
\end{tabular}

${ }^{1} \mathrm{~F}=$ Facilitator and B = Barrier; ${ }^{2} \mathrm{RN}=$ Registered Nurse $;{ }^{3} \mathrm{LTCF}=$ Long-Term Care Facility $;{ }^{4}$ PCC NH $=$ Person-Centered Care Nursing Home $;{ }^{5} \mathrm{CNA}=\mathrm{Certified} \mathrm{Nurse} \mathrm{Assistant;}{ }^{6}$ LNFA = Licensed Nursing Facility Administrator $;{ }^{7} \mathrm{LPN}=$ Licensed Practical Nurse; ${ }^{8} \mathrm{BSN}=$ Nurse with a Bachelor of Science in Nursing. 


\section{References}

1. Department of Economic and Social Affairs. World Population Ageing 2019 Highlights; United Nations: New York, NY, USA, 2019.

2. Mather, M.; Jacobsen, L.A.; Pollard, K.M. Aging in the United States. Popul. Bull. 2015, 70, 1.

3. Mather, M.; Scommegna, P.; Kilduff, L. Fact Sheet: Aging in the United States. Available online: https: //www.prb.org/aging-unitedstates-fact-sheet/\# (accessed on 22 September 2020).

4. McPhillips, D. Aging in America, in 5 Charts. U.S. News World Reports, 30 September 2019.

5. National Center for Health. Long-Term Care Providers and Services Users in the United States, 2015-2016; National Center for Health: Hyattsville, MD, USA, 2019.

6. Abraham, S. Job Satisfaction as an Antecedent to Employee Engagement. SIES J. Manag. 2012, 8, $27-36$.

7. Kaldenberg, D.; Regrut, B. Do satisfied patients depend on satisfied employees? Or, do satisfied employees depend on satisfied patients? QRC Advis. 1999, 15, 9-12.

8. Ganey, P. Achieving Excellence: The Convergence of Safety, Quality, Experience and Caregiver Engagement; Press Ganey: South Bend, IN, USA, 2017.

9. Ganey, P. A Strategic Blueprint for Transformational Change; Press Ganey: South Bend, IN, USA, 2018.

10. Ganey, P. Accelerating Transformation: Translating Strategy into Action; Press Ganey: South Bend, IN, USA, 2019.

11. Syptak, M.; Marsland, D.; Ulmer, D. Job satisfaction: Putting theory into practice. Fam. Pract. Manag. 1999, $6,26$.

12. O'hara, M.A.; Burke, D.; Ditomassi, M.; Lopez, R.P. Assessment of Millennial Nurses' Job Satisfaction and Professional Practice Environment. JONA J. Nurs. Adm. 2019, 49, 411-417. [CrossRef]

13. Middaugh, D.J. Don't feed the bears! Pediatr. Nurs. 2019, 45, 101-102.

14. Dans, M.; Lundmark, V. The effects of positive practice environments. Nurs. Manag. 2019, 50,7-10. [CrossRef]

15. Doherty, E. What Is the Price of Disengaged Healthcare Workers? Available online: https: //electronichealthreporter.com/what-is-the-price-of-disengaged-healthcare-workers/ (accessed on 22 September 2020).

16. Centers for Medicare \& Medicaid Services. Civil Money Penalty Reinvestment Program; Centers for Medicare \& Medicaid Services: Baltiomore, MD, USA, 2018.

17. Dewey, C.; Hingle, S.; Goelz, E.; Linzer, M. Supporting Clinicians during the COVID-19 Pandemic. Ann. Intern. Med. 2020, 172, 752-753. [CrossRef]

18. Zhang, S.X.; Liu, J.; Jahanshahi, A.A.; Nawaser, K.; Yousefi, A.; Li, J.; Sun, S. At the height of the storm: Healthcare staff's health conditions and job satisfaction and their associated predictors during the epidemic peak of COVID-19. Brain Behav. Immun. 2020, 87, 144-146. [CrossRef]

19. Moher, D.; Liberati, A.; Tetzlaff, J.; Altman, D.G. Preferred reporting items for systematic reviews and meta-analyses: The PRISMA statement. Ann. Intern. Med. 2009, 151, 264-269.

20. Mileski, M.; Henriksen, A.; Farzi, J.; Adeleke, I.; Chan, R.; Kruse, C. Writing a Systematic Review for Publication in a Health-Related Degree Program. JMIR Res. Protoc. 2019, 8, e15490. [CrossRef]

21. Viera, A.J.; Garrett, J.M. Understanding interobserver agreement: The kappa statistic. Fam. Med. 2005, 37, 360-363. [PubMed]

22. Aloisio, L.D.; Baumbusch, J.; Estabrooks, C.A.; Boström, A.-M.; Chamberlain, S.; Cummings, G.G.; Thompson, G.; Squires, J.E. Factors affecting job satisfaction in long-term care unit managers, directors of care and facility administrators: A secondary analysis. J. Nurs. Manag. 2019, 27, 1764-1772. [CrossRef] [PubMed]

23. Malagón-Aguilera, M.C.; Suñer-Soler, R.; Bonmatí-Tomas, A.; Bosch-Farré, C.; Gelabert-Vilella, S.; Juvinyà-Canal, D. Relationship between sense of coherence, health and work engagement among nurses. J. Nurs. Manag. 2019, 27. [CrossRef] [PubMed]

24. Escrig-Pinol, A.; Hempinstall, M.; McGilton, K.S. Unpacking the multiple dimensions and levels of responsibility of the charge nurse role in long-term care facilities. Int. J. Older People Nurs. 2019, 14, e12259. [CrossRef]

25. Saito, Y.; Igarashi, A.; Noguchi-Watanabe, M.; Takai, Y.; Yamamoto-Mitani, N. Work values and their association with burnout/work engagement among nurses in long-term care hospitals. J. Nurs. Manag. 2018, 26, 393-402. [CrossRef] 
26. Berta, W.; Laporte, A.; Perreira, T.; Ginsburg, L.; Dass, A.R.; Deber, R.B.; Baumann, A.; Cranley, L.A.; Bourgeault, I.L.; Lum, J.; et al. Relationships between work outcomes, work attitudes and work environments of health support workers in Ontario long-term care and home and community care settings. Hum. Resour. Health 2018, 16, 15. [CrossRef]

27. Matthews, M.; Carsten, M.K.; Ayers, D.J.; Menachemi, N. Determinants of turnover among low wage earners in long term care: The role of manager-employee relationships. Geriatr. Nurs. 2018, 39, 407-413. [CrossRef]

28. Røen, I.; Kirkevold, O.; Testad, I.; Selbæk, G.; Engedal, K.; Bergh, S. Person-centered care in Norwegian nursing homes and its relation to organizational factors and staff characteristics: A cross-sectional survey. Int. Psychogeriatr. 2017, 30, 1279-1290. [CrossRef]

29. Backman, A.; Sjögren, K.; Lövheim, H.; Edvardsson, D. Job strain in nursing homes-Exploring the impact of leadership. J. Clin. Nurs. 2018, 27, 1552-1560. [CrossRef]

30. Doran, K.; Resnick, B.; Swanberg, J. Factors Influencing Job Satisfaction among Long-Term Care Staff. J. Occup. Environ. Med. 2017, 59, 1109-1113. [CrossRef] [PubMed]

31. Cummings, G.G.; Hewko, S.J.; Wang, M.; A Wong, C.; Laschinger, H.K.S.; Estabrooks, C.A. Impact of Managers' Coaching Conversations on Staff Knowledge Use and Performance in Long-Term Care Settings. Worldviews Evid. Based Nurs. 2017, 15, 62-71. [CrossRef] [PubMed]

32. Chamberlain, S.A.; Hoben, M.; Squires, J.E.; Estabrooks, C.A. Individual and organizational predictors of health care aide job satisfaction in long term care. BMC Heal. Serv. Res. 2016, 16, 577. [CrossRef] [PubMed]

33. Zhang, Y.; Punnett, L.; Gore, R. The CPH-NEW Research Team Relationships among Employees' Working Conditions, Mental Health, and Intention to Leave in Nursing Homes. J. Appl. Gerontol. 2012, 33, 6-23. [CrossRef]

34. Kim, B.; Liu, L.; Ishikawa, H.; Park, S.-H. Relationships between social support, job autonomy, job satisfaction, and burnout among care workers in long-term care facilities in Hawaii. Educ. Gerontol. 2019, 45, 57-68. [CrossRef]

35. Bernstein, A. Minimise turnover by keeping staff happy. Nurs. Resid. Care 2018, 20, 48-50. [CrossRef]

36. Keisu, B.-I.; Öhman, A.; Enberg, B. Employee effort-reward balance and first-level manager transformational leadership within elderly care. Scand. J. Caring Sci. 2017, 32, 407-416. [CrossRef]

37. Rao, A.D.; Evans, L.K.; Mueller, C.A.; Lake, E.T. Professional networks and support for nursing home directors of nursing. Res. Nurs. Health 2019, 42, 136-147. [CrossRef]

38. Elliott, K.-E.J.; Rodwell, J.; Martín, A.J. Aged care nurses' job control influence satisfaction and mental health. J. Nurs. Manag. 2017, 25, 558-568. [CrossRef]

39. Knecht, P. Demystifying Job Satisfaction in Long-Term Care: The Voices of Licensed Practical Nurses. Ph.D. Thesis, The Pensylvania State University, State College, PA, USA, 2014.

40. Kirkham, A. Enhancing Nurse Faculty Retention through Quality Work Environments: A Photovoice Project. Nurs. Econ. 2016, 34, 289-295.

41. Chu, C.H.; Wodchis, W.P.; McGilton, K.S. Turnover of regulated nurses in long-term care facilities. J. Nurs. Manag. 2013, 22, 553-562. [CrossRef] [PubMed]

42. McGilton, K.S.; Chu, C.H.; Shaw, A.C.; Wong, R.; Ploeg, J. Outcomes related to effective nurse supervision in long-term care homes: An integrative review. J. Nurs. Manag. 2016, 24, 1007-1026. [CrossRef] [PubMed]

43. Harding, C. Job satisfaction as an alternative approach to staff development. J. Dementia Care 2017, 25, 2.

44. Bethell, J.; Chu, C.H.; Wodchis, W.P.; Walker, K.; Stewart, S.C.; McGilton, K.S. Supportive Supervision and Staff Intent to Turn Over in Long-Term Care Homes. Gerontology 2017, 58, 953-959. [CrossRef]

45. Adams, J.; Verbeek, H.; Zwakhalen, S.M.G. The Impact of Organizational Innovations in Nursing Homes on Staff Perceptions: A Secondary Data Analysis. J. Nurs. Scholarsh. 2017, 49, 54-62. [CrossRef]

46. Tong, M.; Schwendimann, R.; Zúñiga, F. Mobbing among care workers in nursing homes: A cross-sectional secondary analysis of the Swiss Nursing Homes Human Resources Project. Int. J. Nurs. Stud. 2016, 66, $72-81$. [CrossRef]

47. Schwendimann, R.; Dhaini, S.; Ausserhofer, D.; Engberg, S.; Zúñiga, F. Factors associated with high job satisfaction among care workers in Swiss nursing homes-A cross sectional survey study. BMC Nurs. 2016, 15, 37. [CrossRef]

48. Gray, M.; Shadden, B.; Henry, J.; Di Brezzo, R.; Ferguson, A.; Fort, I. Meaning making in long-term care: What do certified nursing assistants think? Nurs. Inq. 2016, 23, 244-252. [CrossRef] 
49. Myers, D.; Rogers, R.; Lecrone, H.H.; Kelley, K.; Scott, J.H. Work Life Stress and Career Resilience of Licensed Nursing Facility Administrators. J. Appl. Gerontol. 2016, 37, 435-463. [CrossRef]

50. Binney, I. Registered Nurses' Perceptions of Work Engagement and Turnover Intentions in a Long-Term Care Facility: A Case Study. Ph.D. Thesis, Northcentral University, Scottsdale, AR, USA, 2014.

51. Wagner, J.I.; Brooks, D.; Urban, A.-M. Health Care Providers' Spirit at Work Within a Restructured Workplace. West. J. Nurs. Res. 2016, 40, 20-36. [CrossRef]

52. Desveaux, L.; Halko, R.; Marani, H.; Feldman, S.; Ivers, N.M. Importance of Team Functioning as a Target of Quality Improvement Initiatives in Nursing Homes. J. Contin. Educ. Health Prof. 2019, 39, 21-28. [CrossRef] [PubMed]

53. Huang, S.S.; Bowblis, J.R. Workforce Retention and Wages in Nursing Homes: An Analysis of Managerial Ownership. J. Appl. Gerontol. 2018, 902-907. [CrossRef] [PubMed]

54. Chamberlain, S.A.; Gruneir, A.; Hoben, M.; Squires, J.E.; Cummings, G.G.; Estabrooks, C.A. Influence of organizational context on nursing home staff burnout: A cross-sectional survey of care aides in Western Canada. Int. J. Nurs. Stud. 2017, 71, 60-69. [CrossRef] [PubMed]

55. Berridge, C.; Tyler, D.A.; Miller, S.C. Staff Empowerment Practices and CNA Retention: Findings from a Nationally Representative Nursing Home Culture Change Survey. J. Appl. Gerontol. 2016, 37, 419-434. [CrossRef]

56. Ginsburg, L.; Berta, W.; Baumbusch, J.; Dass, A.R.; Laporte, A.; Reid, R.C.; Squires, J.; Taylor, D. Measuring Work Engagement, Psychological Empowerment, and Organizational Citizenship Behavior Among Health Care Aides. Gerontology 2016, 56, e1-e11. [CrossRef]

57. Smikle, J.L. Why They Stay: Retention Strategies for Long Term Care. The Reasons That Staff Stay on Have Everything to Do with the Company's Commitment to Them as Individuals. Provider 2015, 41, 39, 40, 42.

58. Zwijsen, S.; Gerritsen, D.; Eefsting, J.; Smalbrugge, M.; Hertogh, C.; Pot, A.M. Coming to grips with challenging behaviour: A cluster randomised controlled trial on the effects of a new care programme for challenging behaviour on burnout, job satisfaction and job demands of care staff on dementia special care units. Int. J. Nurs. Stud. 2015, 52, 68-74. [CrossRef]

59. Jenull, B.; Wiedermann, W. The Different Facets of Work Stress. J. Appl. Gerontol. 2013, 34, 823-843. [CrossRef]

60. Kusmaul, N.; Sahoo, S. Hypothesis Testing of CNA Perceptions of Organizational Culture in Long Term Care. J. Gerontol. Soc. Work 2019, 62, 405-414. [CrossRef]

61. Tsukamoto, E.; Abe, T.; Ono, M. Inverse roles of emotional labour on health and job satisfaction among long-term care workers in Japan. Psychol. Health Med. 2014, 20, 814-823. [CrossRef]

62. Yepes-Baldó, M.; Romeo, M.; Westerberg, K.; Nordin, M. Job Crafting, Employee Well-being, and Quality of Care. West. J. Nurs. Res. 2016, 40, 52-66. [CrossRef] [PubMed]

63. Wendsche, J.; Hacker, W.; Wegge, J.; Schrod, N.; Roitzsch, K.; Tomaschek, A.; Kliegel, M. Rest break organization in geriatric care and turnover: A multimethod cross-sectional study. Int. J. Nurs. Stud. 2014, 51, 1246-1257. [CrossRef] [PubMed]

64. Kim, J.H.; Lee, J.; Lee, S.; Cho, E.J. Quercetin and quercetin-3- $\beta$-d-glucoside improve cognitive and memory function in Alzheimer's disease mouse. Appl. Biol. Chem. 2016, 59, 721-728. [CrossRef]

65. Wallin, A.O.; Jakobsson, U.; Edberg, A.-K. Job strain and stress of conscience among nurse assistants working in residential care. J. Nurs. Manag. 2013, 23, 368-379. [CrossRef] [PubMed]

66. Van Der Zijpp, T.J.; Niessen, T.; Eldh, A.C.; A Hawkes, C.; McMullan, C.; Mockford, C.; Wallin, L.; McCormack, B.; Rycroft-Malone, J.; Seers, K.; et al. A Bridge over Turbulent Waters: Illustrating the Interaction between Managerial Leaders and Facilitators When Implementing Research Evidence. Worldviews Evid. Based Nurs. 2016, 13, 25-31. [CrossRef] [PubMed]

67. Kuo, H.-T.; Lin, K.-C.; Li, I.-C. The mediating effects of job satisfaction on turnover intention for long-term care nurses in Taiwan. J. Nurs. Manag. 2013, 22, 225-233. [CrossRef] [PubMed]

68. Pung, L.-X.; Shorey, S.; Goh, Y.S. Job satisfaction, demands of immigration among international nursing staff working in the long-term care setting: A cross-sectional study. Appl. Nurs. Res. 2017, 36, 42-49. [CrossRef]

69. Backhaus, R.; Verbeek, H.; Van Rossum, E.; Capezuti, E.A.; Hamers, J.P. Baccalaureate-educated Registered Nurses in nursing homes: Experiences and opinions of administrators and nursing staff. J. Adv. Nurs. 2017, 74, 75-88. [CrossRef]

70. Willemse, B.; Depla, M.; Smit, D.; Pot, A.M. The relationship between small-scale nursing home care for people with dementia and staff's perceived job characteristics. Int. Psychogeriatr. 2014, 26, 805-816. [CrossRef] 
71. Butler, S.S.; Brennan-Ing, M.; Wardamasky, S.; Ashley, A. Determinants of Longer Job Tenure Among Home Care Aides: What Makes Some Stay on the Job While Others Leave? J. Appl. Gerontol. 2014, 33, 164-188. [CrossRef]

72. McGilton, K.S.; Boscart, V.M.; Brown, M.; Bowers, B.J. Making tradeoffs between the reasons to leave and reasons to stay employed in long-term care homes: Perspectives of licensed nursing staff. Int. J. Nurs. Stud. 2014, 51, 917-926. [CrossRef] [PubMed]

73. Hartmann, C.W.; Mills, W.L.; Pimentel, C.B.; A Palmer, J.; Allen, R.S.; Zhao, S.; Wewiorski, N.J.; Sullivan, J.L.; Dillon, K.; Clark, V.; et al. Impact of Intervention to Improve Nursing Home Resident-Staff Interactions and Engagement. Gerontology 2018, 58, e291-e301. [CrossRef] [PubMed]

74. Boscart, V.M.; D'Avernas, J.; Brown, P.; Raasok, M. Changing the Impact of Nursing Assistants' Education in Seniors' Care: The Living Classroom in Long-Term Care. Can. Geriatr. J. 2017, 20, 15-21. [CrossRef] [PubMed]

75. Rajamohan, S.; Porock, D.; Chang, Y.-P. Understanding the Relationship between Staff and Job Satisfaction, Stress, Turnover, and Staff Outcomes in the Person-Centered Care Nursing Home Arena. J. Nurs. Scholarsh. 2019, 51, 560-568. [CrossRef] [PubMed]

76. Perreira, T.A.; Berta, W.; Laporte, A.; Ginsburg, L.; Deber, R.B.; Elliott, G.; Lum, J. Shining a Light: Examining Similarities and Differences in the Work Psychology of Health Support Workers Employed in Long-Term Care and Home and Community Care Settings. J. Appl. Gerontol. 2017, 38, 1595-1614. [CrossRef] [PubMed]

77. Wendsche, J.; Hacker, W.; Wegge, J.; Rudolf, M. High job demands and low job control increase nurses' professional leaving intentions: The role of care setting and profit orientation. Res. Nurs. Health 2016, 39, 353-363. [CrossRef]

78. Meyer, D.; Raffle, H.; Ware, L.J. The first year: Employment patterns and job perceptions of nursing assistants in a rural setting. J. Nurs. Manag. 2012, 22, 769-778. [CrossRef]

79. Kim, J.; Wehbi, N.K.; DelliFraine, J.L.; Brannon, D. The joint relationship between organizational design factors and HR practice factors on direct care workers' job satisfaction and turnover intent. Health Care Manag. Rev. 2014, 39, 174-184. [CrossRef]

80. Thompson, J.; Cook, G.; Duschinsky, R. 'I feel like a salesperson': The effect of multiple-source care funding on the experiences and views of nursing home nurses in England. Nurs. Inq. 2014, 22, 168-177. [CrossRef]

81. Jirkovská, B.; Janečková, H. Workplace stress and employees' well-being: Evidence from long-term care in the Czech Republic. Cent. Eur. J. Public Health 2019, 27, 87-92. [CrossRef] [PubMed]

82. Bortolotti, T.; Boscari, S.; Danese, P.; Suni, H.A.M.; Rich, N.; Romano, P. The social benefits of kaizen initiatives in healthcare: An empirical study. Int. J. Oper. Prod. Manag. 2018, 38, 554-578. [CrossRef] 